Michał Jerzy Zacharias

Warszawa

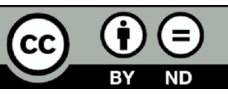

\title{
Antystalinowska „herezja” w jugosłowiańskiej ortodoksji. Stalin, ZSRS i system sowiecki w poglądach politycznych Milovana Đilasa w latach 1950-1952
}

Zarys treści: W swoim artykule Michał Jerzy Zacharias przedstawia myśl polityczną Milovana Đilasa w latach 1950-1952, a więc w okresie głębokiego kryzysu w stosunkach jugosłowiańsko-sowieckich. Kryzysu powstałego w wyniku polityki Stalina i rezolucji Kominformu z 28 czerwca 1948 roku.

Słowa kluczowe: Milovan Đilas, Jugosławia, stosunki jugosłowiańsko-radzieckie, jugosłowiańska ortodoksja komunistyczna

Key words: Milovan Đilas, Yugoslavia, yugoslawian-sowiet relations, Yugoslavian communist orthodoxy

Antystalinowska „herezja” Milovana Đilasa, ujawniona na przełomie lat 40. i 50. $\mathrm{XX}$ w., miała swoisty charakter. Była bowiem elementem miejscowej ortodoksji komunistycznej, w istocie - sztucznej konstrukcji teoretycznej, bez istotnego związku z rzeczywistością. Konstrukcji, która w najlepszym razie przynosiła kosmetyczne zmiany w „budowie” jugosłowiańskiego, „socjalistycznego” ustroju. Miała służyć polityce, głównie uzasadnieniu, że kremlowski dyktator gwałci zasady marksistowskie, jest satrapą, reakcjonistą oraz imperialistą, a także wykazaniu, że prawdziwe cele rewolucyjne, zgodne z naukami Marksa, Engelsa i Lenina ${ }^{1}$, są realizowane w Jugosławii. W rezultacie myśl polityczna Đilasa nadal mieściła się w ramach

${ }^{1}$ Należy jednakże podkreślić, że w późniejszych przekazach Đilas będzie pisał o pewnej ambiwalencji oraz krytyce występującej z czasem w jego poglądach wobec Lenina. Szczegóły: M. Djilas, Rise and Fall, San Diego, New York, London 1985, s. 267; idem, Chrystus i komisarz, [w:] Stalin i stalinizm. Rozmowy George’a Urbana, London 1987, s. 160-161, 200; M. J. Zacharias, Między marzeniami a rzeczywistościq. Myśl polityczna Milovana Djilasa na przełomie w latach 1953 i 1954 r., „Dzieje Najnowsze” 2010, 3, s. 48; idem, Od stalinizmu do „herezji”. Myśl polityczna Milovana Đilasa w latach 1941-1949, „Studia z Dziejów Rosji i Europy Środkowo-Wschodniej”, 2012, 47, s. 115. 
ideologii i propagandy jugosłowiańskiego kierownictwa partyjnego. Z tym tylko, że była spójniejsza i jednorodniejsza niż w latach 1941-1949. Konflikt ze Stalinem i utrata złudzeń w sprawie jego rzeczywistych celów umożliwiały konsekwentną krytykę i potępienie sowieckiej polityki, poniechanie uprzednich hołdów i pisania panegiryków opiewających moskiewskiego „geniusza”. Krytyka ta w praktyce nie odbiegała od tego, co wówczas głosili inni ideolodzy jugosłowiańscy, z Edvardem Kardeljem i Borisem Kidriciem na czele, niezależnie od wstrzemięźliwego czasami stanowiska Tity czy oporu „betonowej”, „twardogłowej” części aparatu KPJ ${ }^{2}$. Istotne było także to, że wydarzenia bieżącej polityki w mniejszym stopniu niż poprzednio wpływały na zasadniczy bieg myśli Đilasa. Ponadto, uwolniona od pierwotnej fascynacji Stalinem i stalinizmem, taktycznych wahań i wybiegów przywództwa KPJ w polityce wobec Moskwy i powstająca w związku z nowymi lekturami i przemyśleniami, myśl polityczna Đilasa ulegała wyraźnemu pogłębieniu. Nadal była instrumentem polityki i propagandy KPJ, ale z wyraźną tendencją unikania płytkiego, $\mathrm{w}$ istocie prymitywnego słownictwa i takiż argumentów. Od tej pory odwołania Đilasa do bieżących wydarzeń wyraźnie będą pozostawać w cieniu jego wywodów teoretycznych; wywodów dotyczących także ogólnych procesów politycznych i historycznych oraz systemów politycznych. Często jest w nich dostrzegalna wnikliwa analiza stalinowskiej rzeczywistości, globalnej sytuacji politycznej, charakteru konfrontacji między światem kapitalistycznym i ,socjalistycznym”, przemian w krajach zachodnich, z USA na czele. Niezależnie od faktu, że niektóre sądy i oceny Đilasa mogą wydawać się wątpliwe czy kontrowersyjne.

Przedstawiając dogłębną, zasadniczą krytykę stalinizmu, Đilas stwierdzi w marcu 1950 r. - przyznajmy, że w tym wypadku niezbyt odkrywczo, powielając znane stanowisko „klasyków” - że „między odejściem od kapitalizmu i dojściem do komunizmu niezbędny jest «okres przejściowy»", różnie nazywany - „socjalizmem”, "niższą fazą komunizmu”. Powstaje wtedy „socjalistyczna demokracja”, tj. tzw. dyktatura proletariatu. Ta dyktatura niewątpliwie jest pozostałością po dawnym „społeczeństwie klasowym”, ale w tym wypadku spełnia pozytywną rolę, bowiem staje się „instrumentem siły” stosowanym przez zdecydowaną większość wobec znikomej mniejszości. Ma zlikwidować opór burżuazji oraz innych „reakcyjnych klas” społecznych, zapobiec odbudowie „starego porządku”, a następnie - przygotować warunki do własnego „zaniku”.

Jednakże tego „zaniku” nikt i nic nie może zagwarantować. Powołując się na Marksa i Lenina, podwładny Tity stwierdza, że obok dawnej, obalonej burżuazji może się pojawić nowy przeciwnik - biurokracja, powstająca w nowym, rewolucyjnym porządku społecznym. Dotyczy to każdego kraju, w którym miała miejsce rewolucja, także

${ }^{2} \mathrm{~W}$ praktyce chodzi tu nie tylko o byłych aparatczyków, o tzw. kominformowców, jugosłowiańskich komunistów, którzy w 1948 r. opowiedzieli się po stronie Stalina, lecz również i o tych funkcjonariuszy KPJ, którzy z różnych względów poparli wówczas Titę. O stalinowskiej indoktrynacji KPJ, głównie w czasie wojny, zob. V. Dedijer, Dziennik, t. 2, Beograd 1970, s. 392-398.

${ }^{3}$ M. Djilas, On New Roads of Socialism. Addresses Delivered at the Pre-Election Rally of Belgrade Students, March 18, 1950, Belgrade 1950, s. 8. 
Jugosławii. Byłaby to „uprzywilejowana kasta” sprawująca niekontrolowane rządy i żyjąca „na koszt całego społeczeństwa”4. Powstanie takiej grupy wynikałoby z niekorzystnej, w tym wypadku, ewolucji „dyktatury proletariatu” ${ }^{2}$. To właśnie wydarzyło się w Związku Sowieckim. Pojawiła się tam „uprzywilejowana warstwa biurokratyczna”, „biurokratyczny centralizm”, a także nastąpiło „tymczasowe (? - MJZ) przekształcenie państwa »w siłę stojącą ponad społeczeństwem «"6. Taką sytuację wytworzyły różne okoliczności: „zewnętrzne i wewnętrzne słabości sił rewolucyjnych; relatywnie nikła świadomość mas, utrudniająca budowę socjalizmu ${ }^{7}$, długotrwałe istnienie Związku Sowieckiego jako ,jedynego państwa socjalistycznego" we wrogim, kapitalistycznym otoczeniu, zacofanie tego kraju ${ }^{8}$. Z kontekstu można wnioskować, że Đilas ma na myśli całą społeczną i gospodarczą rzeczywistość w tym państwie.

Powstanie biurokratycznej „kasty” wyrastającej z „dyktatury proletariatu”, a w istocie - z monopolu władzy Stalina i jego podwładnych spowodowało liczne negatywne konsekwencje. Przede wszystkim utrudniło, a nawet uniemożliwiło właściwą „budowę socjalizmu” w ZSRS. Nie oznacza groźby restytucji kapitalizmu, jest tylko zupełnie nowym zjawiskiem, „na gruncie i w ramach samego socjalizmu”. Zjawiskiem wyrażającym się w fakcie, że nowe, „socjalistyczne” stosunki własności i rozwój sił wytwórczych w ZSRS nie znajdują właściwej metody zarządzania tą własnością i tymi siłami. W odróżnieniu od sytuacji w Jugosławii ${ }^{9}$ to zarządzanie polega na dominującej roli biurokracji, z pominięciem mas, bezpośrednich wytwórców. Wyrażając cały czas przywiązanie do marksizmu, sięgając do jego określeń, pojęć i kategorii, Đilas konstatuje istnienie antagonizmu między siłami wytwórczymi i stosunkami produkcji. Argumentuje, że biurokratyczne metody zarządzania są równoznaczne ze „zmonopolizowaniem przez państwo zarządzania materialną produkcją” ${ }^{10}$, a co za tym idzie - $\mathrm{z}$ anarchizacją tego procesu. Można by temu zapobiec jedynie wtedy, gdyby zgodnie z poglądami samego Marksa wolne związki producentów same zarządzały produkcją.

${ }^{4}$ Ibidem, s. 9-10.

${ }^{5}$ Ibidem, s. 7 n.

${ }^{6}$ Ibidem, s. 13.

7 Dosłownie: the masses had a relatively weak conscious role in the struggle for socialist building, ibidem, s. 13. Na marginesie można by zaznaczyć, że Rosja była krajem przede wszystkim rolniczym, co powodowało, że skupiska robotnicze, stosunkowo nieliczne i słabe, siłą rzeczy nie mogły stać się, w zgodzie z komunistyczną ideologią, bazą przyszłej rewolucji. W istocie jesienią 1917 r. mieliśmy do czynienia nie tyle z rewolucją, ile zamachem stanu, zob. R. Pipes, Rewolucja rosyjska, Warszawa 1994, s. 350 n. Można również zauważyć, że tytuł książki pozornie przeczy tezie o zamachu przedstawionym w rozdziale 11., zatytułowanym Październikowy zamach stanu (ibidem, s. 350 n.). Z treści rozdziału 1. pracy (ibidem, s. 3) wynika jednakże, że wydarzenia z 1917 r. Pipes omawia w szerszej perspektywie czasowej, sięgając do XVIII wieku. Daje on do zrozumienia, że sam zamach, a więc to, co się wydarzyło w październiku 1917 r., był tylko elementem szerszego zjawiska, w pełni uzasadniającego tytuł jego pracy.

${ }^{8}$ M. Djilas, On New Roads of Socialism..., s. 13.

9 Ibidem.

10 Ibidem, s. 14. 
Zdaniem Đilasa, dominująca pozycja biurokracji, rodząca m.in. tę anarchizację, jest zasadniczą przyczyną stagnacji, a nawet kryzysu socjalizmu w ZSRS ${ }^{11}$. W rezultacie sowieccy biurokraci, którzy „spetryfikowali swoją uprzywilejowaną pozycję”, usiłują przykryć wewnętrzne trudności, przynajmniej tymczasowo, swoją działalnością zewnętrzną, sukcesami w polityce zagranicznej, na drodze „eksploatacji i podporządkowania sobie innych krajów socjalistycznych". Stanowisko sowieckie, wyrażone w rezolucji Kominformu z 28 VI 1948 r. jest tylko symptomem takiej polityki. Z faktu zaś - twierdzi Đilas - że „metody wyzysku i podporządkowania ludów we współczesnym świecie (...) mogą być tylko kapitalistyczne”, gdyż jest on „podzielony”, ale z rynkiem globalnym „ciągle zdominowanym” przez kapitalizm wynika, że wspomniane metody, w rezultacie przewagi tego systemu muszą wyrastać z reguł, które są przezeń narzucane, tj. z „walki o strefy wpływów” i hamowania „dalszego rozwoju socjalizmu” na świecie; „Z walki o zwycięstwo socjalizmu jedynie tu (jak wynika z kontekstu - w ZSRS i krajach od niego zależnych - MJZ)", ale tylko "do tego stopnia i w takiej formie, która odpowiada wąskim, hegemonistycznym celom uprzywilejowanej warstwy” - w „Kraju Rad” i państwach satelickich. To właśnie sprawia, że to, co jest żywotnie korzystne dla tej grupy, staje się „teoretycznie prawdziwe i uzasadnione”. Prowadzi do podsycania „wielkorosyjskiego nacjonalizmu”, „mrocznych instynktów” zacofanych mas w ZSRS, powstania „, biurokratycznej ekspansji i dominacji nad innymi narodami”. Powoduje także, iż „wewnętrzne sprzeczności” między „biurokratycznym centralizmem i bezpośrednimi producentami” rodzą przesłanki do konfliktu między „biurokratycznym imperializmem i aspiracjami ludu do wolności i równości” ${ }^{\prime 2}$.

„Reakcyjne i konserwatywne” dążenia stalinowskie muszą wywołać - twierdzi Đilas - zdecydowane przeciwdziałanie „naszej partii i mas ludowych” Jugosławii. Ich walka o urzeczywistnienie "postępowych tendencji w socjalizmie” będzie miała wymiar historyczny, ponieważ żadne państwo socjalistyczne nie postępowało i nie postępuje tą drogą. "Jesteśmy heglowską negacją obecnego stanu w socjalizmie i tym samym iskrą i zaczynem jego dalszego rozwoju”. „Nasza rewolucja” przekracza narodowe granice „i staje się zjawiskiem o międzynarodowym znaczeniu”"13.

W taki sposób Đilas wyrażał własne i szerzej - ogólne przekonania przywódców KPJ, że Jugosławia zaczyna być wzorem „prawdziwego” socjalizmu, „budowanego” w dialektycznej negacji systemu stalinowskiego. Równocześnie ten czołowy teoretyk jugosłowiańskiej partii krytykował postawę "niektórych towarzyszy”, którzy ahistorycznie i niezgodnie z prawami dialektyki „wyrażają zdziwienie”, dlaczego „nie dostrzegaliśmy” negatywnych zjawisk w ZSRS wcześniej. W odpowiedzi Đilas argumentował, że jedynie „nabyta praktyka rewolucyjna” umożliwia twórcze uściślanie czy też przekształcanie założeń marksizmu. W związku z tym można „coś zanegować teoretycznie” tylko w wyniku wcześniejszego „zbiorowego eksperymentu

\footnotetext{
${ }^{11}$ Ibidem, s. 16.

${ }^{12}$ Ibidem, s. 16-18.

${ }^{13}$ Ibidem, s. 21.
} 
i rewolucyjnej praktyki milionów w społecznej walce. Nowa teoria naukowa, jeśli faktycznie ma nią być, nie może być stanowiona wcześniej”. To właśnie praktyka tworzy i ulepsza teorię. „Tylko ci, którzy kochali Związek Sowiecki najbardziej”, którzy wspólnie z nim „najkonsekwentniej” walczyli o „socjalizm”, mogą „swobodnie i prawomocnie krytykować obecną sytuację w tym kraju", czy szerzej - podawać w wątpliwość obecny stan „socjalizmu” 14 .

Zdaniem Đilasa, walka z biurokracją, a więc „śmiertelnym wrogiem komunizmu i socjalistycznej demokracji (...), mas pracujących i poszczególnych jednostek"15, musi być prowadzona niezależnie od stanowiska różnych „doktrynerów i dogmatyków”, zapatrzonych w przeszłość, postępujących zgodnie z książkową wiedzą i zakłopotanych z powodu niewiedzy, co stanie się z „centrum rewolucji (...), główną siłą socjalizmu", tj. ZSRS w przypadku urzeczywistnienia jugosłowiańskich założeń. Nie zaprzeczają oni, że „mamy rację, ale ..., ale nasze stanowisko ..., niestety! ... osłabia »centrum « i »główną siłę«, stąd należy (...) ... niestety! - podporządkować jej” własne działania. Ale taka „nędzna - głosi Đilas - oportunistyczna logika” nie przyniesie niczego dobrego „socjalizmowi”. Przede wszystkim zaś trzeba pamiętać, że „»centrum «i »głównej siły « nie można umieścić tam, gdzie założenia marksizmu-leninizmu zostały porzucone”. Należałoby je lokować przede wszystkim w miejscu, w którym „rozwój socjalistycznej teorii i praktyki postępuje naprzód”. Co nie oznacza, by Jugosławia stawała się takim „centrum”. Nie jest to możliwe ani potrzebne. Sedno sprawy wiąże się głównie z koniecznością „konsekwentnego zachowania i rozwoju marksistowskiej teorii i praktyki”. W rezultacie „nasza partia i nasz kraj” pełnią jedynie rolę "pionierów w walce o nowe, prawdziwie socjalistyczne stosunki między narodami i państwami, a także - o dokładne zastosowanie nauk marksistowsko-leninowskich o roli państwa w socjalizmie, o umocnieniu i rozwoju socjalistycznej demokracji”. „Nasza rewolucja” może stanowić przykład dla innych ludów i narodów, wykazując im równocześnie, że walka o „socjalizm” musi być jednoznaczna $z$ walką przeciwko „kapitalistycznemu imperializmowi” i „próbom ustanowienia »socjalistycznej« hegemonii" 16 .

Ostatecznie Đilas stawia oba imperializmy - zachodni i sowiecki - na jednej płaszczyźnie. „Ujarzmienie, wyzysk i uniemożliwienie wolnego, socjalistycznego rozwoju w nowych krajach socjalistycznych (...) zasadniczo zmieniło charakter stosunków Związku Sowieckiego z głównym państwem kapitalistycznym zachodniego świata, tj. Stanami Zjednoczonymi”. Narzucając i „czyniąc prawem” hegemonię „przewodniej siły”, a więc swej własnej, kremlowscy przywódcy przekształcili konflikt „między dwoma systemami” z walki o zniszczenie kapitalizmu w zmagania o podział świata na kapitalistyczne i „socjalistyczne” strefy wpływów, podporządkowane USA i ZSRS ${ }^{17}$. W praktyce stali się przeciwnikami rewolucji, co sprawia,

\footnotetext{
${ }^{14}$ Ibidem, s. 21-22.

${ }^{15}$ Ibidem, s. 24.

16 Ibidem, s. 29-31.

${ }^{17}$ Ibidem, s. 28.
} 
że rewolucjoniści w różnych krajach, biorący przykład z Jugosławii, będą musieli się przeciwstawiać obu tym mocarstwom. Wrogiem jest nie tylko międzynarodowa i rodzima burżuazja, ale i sowiecka ,socjalistyczna” biurokracja. Zgodnie z marksizmem-leninizmem głównym celem rewolucji ma być „wszechstronne uwolnienie inicjatywy mas”, w wyniku coraz większego, „śmielszego” wciągania jej „w zarządzanie państwem oraz gospodarką". Stanie się ono praktyczną realizacją „zasady ludowego samorządu"18.

Takie stanowisko, zgodne z ogólną linią polityczną jugosłowiańskiego kierownictwa partyjno-państwowego, wynikało, jak pisze Đilas, z coraz wnikliwszej analizy myśli Marksa, początkowo przeciwstawianej Stalinowi, a z czasem - także Leninowi ${ }^{19}$. Była ona studiowana zarówno przez Đilasa, jak i inne osobistości partyjne. Szczególną uwagę autora Nowej klasy miały wzbudzać te fragmenty drugiego tomu Kapitału Marksa, które były poświęcone „związkom bezpośrednich wytwórców, będącym formą przejścia do komunizmu”. W rezultacie miał on bliżej zainteresować się kwestiami ekonomicznymi, dotychczas pomijanymi $\mathrm{w}$ jego pismach i rozmyślaniach. Zaczynały one się pojawiać w dyskusjach, które prowadził z Kardeljem i Kidriciem, także z powodu „ślepego zaułka”, w jakim znalazła się „nasza gospodarka”. Đilas miał wówczas dojść do przekonania, że „nasz mechanizm gospodarczy należałoby uprościć, tak by całe zarządzanie przedsiębiorstwami przekazać tym, którzy w nich pracują". W tych warunkach uległaby drastycznemu pomniejszeniu rola państwa $w$ gospodarce, ponieważ zgodnie z przekazem Đilasa, państwo zatrzymałoby „dla siebie jedynie podatki” ${ }^{20}$. Pisze on, że idea samorządności była pomysłem jego i Kardelja, wspieranych przez „towarzysza Kirdicia”. Miała być podstawą powstania „społeczeństwa przyszłości", w którym dobrowolnie zrzeszeni producenci sami podejmowaliby decyzje dotyczące produkcji i dystrybucji, co oznaczałoby, że decydują „o własnym życiu i własnej przyszłości”21. Takie określenia niewątpliwie były utrzymane $\mathrm{w}$ duchu tego, co zazwyczaj kojarzy się z XIX-wiecznym „socjalizmem utopijnym”. Miały rzekomo umożliwiać powstanie siły skutecznie ograniczającej czy likwidującej wszechwładzę „socjalistycznej” biurokracji ${ }^{22}$. Podobnie jak poglądy innych jugosłowiańskich teoretyków stawały się punktem wyjścia stopniowego, choć powolnego i niekonsekwentnego, w istocie jedynie proklamowanego „budownictwa

${ }^{18}$ Ibidem, s. 31.

${ }^{19}$ M. Djilas, Une société imparfaite. Le communisme désintegré, Paris 1969, s. 239.

${ }^{20}$ Ibidem, s. 262 n.; idem, Pad nove klase. Povest o samorazaranju komunizma, Beograd 1994, s. 110.

${ }^{21}$ Idem, Une société imparfaite..., s. 262.

${ }^{22}$ Należałoby dodać, że jugosłowiańskie koncepcje ustrojowe opierały się, jak trafnie zauważa Jerzy Ciemniewski, „na wizji bardzo w gruncie rzeczy ograniczonych potrzeb jednostki”. Ponadto, trudno było się spodziewać, że istotnie mogą one być zrealizowane „w niewielkich społecznościach, produkcyjnych i komunalnych", pozbawionych - dodajmy od siebie - jakiejkolwiek wspólnej reprezentacji politycznej, mogącej równoważyć władzę ZKJ. Ponadto, wspomniane koncepcje nie uwzględniały „możliwości powstania zasadniczych kolizji między interesem dwóch kategorii samorządu - terytorialnego i produkcyjnego". J. Ciemniewski, System delegacki na tle ewolucji ustroju politycznego Socjalistycznej Federacyjnej Republiki Jugosławii, Wrocław 1988, s. 40. 
socjalistycznego" w wersji samorządowej. Zapoczątkowanego przez Titę przedstawieniem w Skupsztynie w dniu 26 VI 1950 r. projektu ustawy „o robotniczym zarządzaniu przedsiębiorstwami gospodarczymi”23. Jeśliby potraktować poważnie tę nową, swoistą konstrukcję „socjalistyczną" i stojące u jej podstaw założenia, to należałoby postawić pytanie, jaką rolę przeznaczali jugosłowiańscy teoretycy partii i państwu w swoim systemie ustrojowym. Odpowiedzi, udzielane wówczas przez Đilasa, nie odbiegały od poglądów głoszonych przez innych polityków oraz ideologów jugosłowiańskiej partii komunistycznej. Idąc ich śladem, Đilas przedstawiał swoje stanowisko $w$ różnych pismach, referatach i wypowiedziach. W rezultacie niezbędna staje się dokładna analiza ich treści, m.in. Aktualnych problemów ${ }^{24}$, opublikowanych w „Borbie” w drugiej połowie listopada $1950 \mathrm{roku}^{25}$. Đilas nadal podważał w nich i krytykował sowieckie wzorce ustrojowe, stalinowską biurokrację, ponurą rzeczywistość „Kraju Rad”. Rozwijał swoją dotychczasową argumentację, najczęściej w nawiązaniu do wyrażonych już myśli, pisząc na przykład dosadnie, że „zamiast radosnych i swobodnych form życia duchowego i społecznego ludzi pracy, który się pozbyli »opieki« kapitalistycznych panów i feudalnych wielmoży” zapanowała „szara, jednostajna myśl, szalone, nieludzkie i pijackie wylewy opatentowanego szczęścia, jak i gwałtowny oraz całkowity ucisk żelaznych pęt (...), dotychczas nieznany w historii ludzkości”. Sponad „zabalsamowanego ciała Lenina” wyłaniają się ci, którzy spetryfikowali, „zabalsamowali jego myśl i (...) dzieło”26. Uniemożliwiając rozwój i przedstawianie jakichkolwiek śmielszych i oryginalnych idei marksistowskich w ZSRS. Co oczywiście nie oznacza, że te osobistości, tj. przedstawiciele rządzącej biurokracji, od samego początku spełniały negatywną rolę. Wprost przeciwnie, ich władza przez pewien czas była niezbędna, przyczyniała się do powstania, utrwalenia i rozwoju „socjalizmu”. Biurokraci i „biurokratyczne tendencje" wyrastają bowiem „z dyktatury proletariatu (...), z proletariackiej rewolucji” ${ }^{27}$, umożliwiają przejęcie „przez państwo własności prywatnego kapitału i zarządzanie nim”. Są nieuniknione zarówno w przypadku Jugosławii, jak i każdego innego „socjalistycznego” państwa bezpośrednio po zwycięstwie rewolucji. Mamy wtedy do czynienia „z okresem państwowej własności środków produkcji” w „socjalizmie”. Niemniej, w miarę upływu czasu, kiedy rozwój wymaga zmiany w zarządzaniu nimi, stosunki produkcji z dominującą rolą państwa i biurokracji nieuchronnie stają się „zawadą i hamulcem” w "budowie socjalizmu”. W rezultacie albo ustąpią miejsca "wyższej formie stosunków socjalistycznych",

${ }^{23}$ J. Broz Tito, O radničkom upravljanju preduzecima, Beograd, 26 jul 1950 godine, [w:] Dokumenti 1948, red. V. Dedijer, t. 3, Beograd 1983, s. 83-107.

${ }^{24}$ M. Đilas, Savremene teme, Beograd 1950

${ }^{25}$ Tytuły poszczególnych artykułów wchodzących w skład Aktualnych problemów oraz daty wydania: Pojave i suština Sovjetskog Saveza, „Borba”, 19 i 20 XI 1950 r.; Dva ili jedan svijet prožet nepomirljivim protivrečima, „Borba”, 26 XI 1950 r.; Naša dosadašnja iskustva u borbi za socijalizam, „Borba”, 29 XI 1950 roku.

${ }^{26}$ Idem, Savremene teme, s. 4

${ }^{27}$ Ibidem, s. 41. 
tj. „własności ogólnonarodowej zarządzanej przez bezpośrednich producentów”, albo zostaną zastąpione przez państwowo-kapitalistyczne, z dominującą rolą biurokracji w kierowaniu gospodarką ${ }^{28}$.

Zdaniem Đilasa, te ostatnie tendencje, widoczne w ZSRS, są elementem szerszego procesu dostrzegalnego w krajach kapitalistycznych, tj. ewolucji ich gospodarki i zmiany roli państwa na tym polu. Powołując się na Marksa i Engelsa, autor Aktualnych problemów stwierdza, że tworzenie monopoli jest świadectwem „zbędności (? - MJZ) kapitalistycznej własności”, ponieważ „cała praca”, a więc zarządzanie, przechodzi w ręce „opłacanych urzędników”. W organizowaniu i kierowaniu gospodarką coraz widoczniej zastępują oni „starego, klasycznego właściciela kapitalistę". Następuje liczebny wzrost biurokracji ${ }^{29}$ oraz przekazywanie zarządzania przedsiębiorstwami, całą gospodarką urzędnikom, co jest „naturalnym (...) procesem w monopolistycznej fazie rozwoju kapitalizmu”. Obecnie rola właścicieli sprowadza się głównie do ogólnej kontroli i „odcinania kuponów (...) stara, klasyczna burżuazja rozpada się na bezczynnych, uprzywilejowanych i zblazowanych rentierów, którzy z głębi duszy nienawidzą cały rodzaj ludzki (...) i na masę urzędników i zarządców monopoli”. Równocześnie wzrasta rola państwa i kapitału państwowego w gospodarce. „Sam rozwój monopoli, o którym mówił jeszcze Engels”, doprowadził do powstania warunków umożliwiających odebranie przedsiębiorstw „kapitalistycznym właścicielom”30.

To „odebranie” nie nastąpi jednakże automatycznie. Niezależnie bowiem od oceny możliwości urzeczywistnienia tego procesu, Đilas w nieco mętnym i pokrętnym wywodzie argumentuje, że w państwach kapitalistycznych nie można tego zrealizować „do końca”, właśnie z powodu ich charakteru (jak pisze - „państwowo-kapitalistycznego"). Pozbawienie prywatnego właściciela „funkcji własności” (? - MJZ. Zgodnie z logiką swego rozumowania Đilas winien chyba napisać „roli zarządzania”) spowodowało tylko to, że go zastąpił „ktoś inny”, tj. państwo. Niemniej działania państwa dowodzą nie tylko tego, że „monopole i system monopolowy można utrzymać i rozwijać (...) jedynie z pomocą tych działań, ale że upaństwowienie, inaczej nacjonalizacja, względnie - przejście zmonopolizowanej własności w ręce ludu", zerwanie więzi sił wytwórczych ze zmonopolizowaną, kapitalistyczną strukturą jest koniecznym warunkiem „niezakłóconego rozwoju tych sił” oraz postępu społecznego w przyszłości ${ }^{31}$.

W rezultacie Đilas wyraźnie sugeruje rozwój dwóch pokrewnych procesów. Pierwszym z nich jest stopniowa ewolucja systemu zdominowanego na Zachodzie przez monopole w kierunku kapitalizmu państwowego. Można by dyskutować, czy ta sugestia nie jest przezeń akcentowana zbyt mocno, ale równocześnie nie można zaprzeczyć istnieniu faktów, które potwierdzałyby, zarówno w czasie publikacji

\footnotetext{
${ }^{28}$ Ibidem, s. 46.

${ }^{29}$ Ibidem, s. 8. Mając na uwadze liczebny wzrost biurokracji w krajach kapitalistycznych, Đilas podaje nietypowy, jak się wydaje, przykład III Rzeszy. Szczegóły, ibidem, s. 11-12.

${ }^{30}$ Ibidem, s. 12

${ }^{31}$ Ibidem, s. 12-13.
} 
Aktualnych problemów, jak i w późniejszych latach, nie tyle powstawanie omnipotencji, ile zwiększenie roli państwa w gospodarce oraz w stosunkach gospodarczo-społecznych, a także występowanie poglądów $\mathrm{w}$ istocie zgodnych $\mathrm{z}$ przemyśleniami i wnioskami Đilasa. O potrzebie zwiększenia roli państwa jeszcze przed II wojną światową pisał John Maynard Keynes, w związku z kryzysem z lat 1929-1933². Istotne znaczenie mają również obserwacje poczynione przez Jamesa Burnhama. Już w 1941 r. wystąpił on z tezą, że rozwój prowadzi do powstawania społeczeństwa zarządców, kierowników, specjalistów, że współczesny kapitalizm znajduje się w okresie nowej rewolucji. Wyłania ona nową klasę zarządzającą, tj. menedżerów. Stopniowo zastępuje ona tradycyjnych kapitalistów, zyskuje kontrolę nad środkami produkcji i przywileje w zakresie podziału dochodu społecznego ${ }^{33}$.

Takie idee występowały równocześnie z powstaniem i rozbudową tzw. państwa opiekuńczego, różnych form jego interwencji w gospodarkę i kwestie społeczne, z pewnym ograniczeniem, choć nierównomiernie, dominacji rynku ${ }^{34}$. „Panowało powszechne przekonanie, że państwo zawsze poradzi sobie lepiej niż niczym nieograniczony rynek ${ }^{35}$ - nie tylko, gdy chodzi o wymiar sprawiedliwości i bezpieczeństwo państwa czy dystrybucję towarów i usług, ale też planowanie i wprowadzanie w życie strategii służących społecznej spójności, trwałości zasad moralnych i żywotności kulturowej. Wyobrażenie, że takie sprawy lepiej pozostawić światłemu interesowi własnemu oraz mechanizmom wolnego rynku dóbr i idei, w dominujących europejskich kręgach politycznych i naukowych uznawano za dziwaczny relikt czasów

${ }^{32}$ Głównie w pracy The General Theory of Employment, Interest and Money, New York 1935, wyd. polskie Ogólna teoria zatrudnienia, procentu i pieniadza, Warszawa 1956

${ }^{33}$ Zob. J. Burnham, Managerial Revolution or what is happening in the World now, London 1942. Nie dysponujemy informacjami, czy Đilas znał tę pracę i czy rozważania Burnhama nie wpływały przynajmniej w ograniczonym stopniu na jego rozważania. Niemniej trudno byłoby taką hipotezę apriorycznie odrzucić. Można by także dodać, że warstwa zarządzająca w samej Jugosławii szczyt swoich wpływów i możliwości osiągnęła na przełomie lat 60. i 70. XX w., w okresie reform w tym kraju. Była powiązana $\mathrm{z}$ aparatem władzy różnorodnymi interesami i zależnościami, ale starała się - $\mathrm{i}$ w tym tkwiłaby niejaka różnica w porównaniu z poglądami Đilasa - akcentować pewną autonomię i swoje merytoryczne walory. W późniejszej literaturze przedmiotu przedstawicieli tej grupy nazywano, podobnie zresztą jak w innych krajach, głównie zachodnich, mianem technokratów lub technostruktury, zob. M. J. Zacharias, Komunizm, federacja, nacjonalizmy. System władzy w Jugosławii 1943-1991. Powstanie, przekształcenia, rozkład, Warszawa 2004, s. 229-230 i n.

${ }^{34}$ O „państwie dobrobytu”, T. Judt, Powojnie. Historia Europy od 1945, Poznań 2008, s. 426 n. Niemniej Judt bardzo trafnie dostrzega podobieństwa, ale i różnice między państwami tego typu. Zwraca uwagę, że powiększenie roli państwa jako zasadniczego środka gwarantującego bezpieczeństwo socjalne pracobiorców nie musiało iść w parze z kwestionowaniem własności prywatnej i dobroczynnej roli rynku. Pisze m.in., że „w całej Skandynawii, ale szczególnie w Szwecji, nigdy nie kwestionowano prywatnej własności środków produkcji. W przeciwieństwie do brytyjskiej Partii Pracy, której fundamentalna doktryna i program od 1918 r. opierały się na niezachwianej wierze w zalety własności państwowej, szwedzcy socjaldemokraci pozostawili kapitał i inicjatywę w rękach prywatnych. Szwecja nigdy nie wzięła przykładu z Wielkiej Brytanii i British Motor Corporation, bezradnego królika doświadczalnego w rządowych eksperymentach z centralnym rozdzielnictwem środków. Volvo, Saab i inne prywatne przedsiębiorstwa pozostawiono w spokoju, by się rozwijały lub upadały", ibidem, s. 434 .

${ }^{35}$ Ale przy uwzględnieniu różnic i specyfiki, przedstawionej w przypisie 34 . 
przedkeynesowskich - w najlepszym razie była to dla nich nieumiejętność wyciągnięcia nauki z Wielkiego Kryzysu, w najgorszym zachęta do konfliktu i zawoalowane odwoływanie się do najniższych ludzkich instynktów (...). Wiara w państwo, które planuje, koordynuje, pomaga, rozstrzyga spory, żywi, opiekuje się i strzeże, była powszechna i przekraczała niemal wszystkie polityczne podziały. Państwo opiekuńcze zgodnie z własną deklaracją miało charakter socjalny, ale daleko mu było do państwa socjalistycznego" ${ }^{36}$.

W zasadzie, zgadzając się z oceną dotyczącą rozszerzenia funkcji współczesnego państwa Đilas zapewne by dodał, iż nie tylko nie jest ono „socjalistyczne”, ale i nie aspiruje do jakiejkolwiek „opiekuńczości” w sensie, jaki nadaje temu pojęciu Tony Judt. A także, że powstawaniu takiego państwa towarzyszy drugi ze wspomnianych procesów, tj. rozwój stosunków państwowo-kapitalistycznych w ZSRS. W tym ujęciu przypominałoby to późniejsze teorie konwergencyjne, występujące w latach 60. i 70. XX wieku' ${ }^{37}$.

Đilasa można by więc uznać za swoistego prekursora tych koncepcji. Niewątpliwie byłby jednym $z$ wielu. Niemniej jego przemyślenia były inspirowane marksizmem i wyrażały przekonanie, że państwo sowieckie coraz mniej jest „socjalistyczne”. To zaś mogło by oznaczać odrzucenie poglądu widocznego jeszcze w marcu $1950 \mathrm{r}$. o „socjalistycznym” charakterze tego kraju ${ }^{38}$. Było nie tyle, a w każdym razie nie tylko konstatacją upodabniania się obu systemów, jak u zachodnich „konwergencjonistów”, ile zarzutem o „zdradę” dawnych ideałów rewolucyjnych; zarzutem kierowanym w stronę Moskwy.

Istota rzeczy, istota „zdrady” miała sprowadzać się do tego, że to, co na początku, bezpośrednio po przechwyceniu władzy, zgodnie z duchem myśli Đilasa, jawiło się jako zwycięstwo "proletariatu” i było niezbędne oraz nieuniknione, tj. dominacja „socjalistycznej” biurokracji, z czasem ulegało petryfikacji, stawało się stałym, niezbywalnym elementem ustrojowym, usuwającym w cień władzę mas ludowych. Niezależnie od faktu, że w odróżnieniu od sytuacji panującej w krajach kapitalistycznych, „socjalistyczna” biurokracja miała sprzyjać zupełnie innej tendencji rozwojowej: nie umocnieniu, lecz obumieraniu państwa i zwycięstwu komunizmu; likwidacji państwa kapitalistycznego i powstaniu „proletariackiego”, w którym następowałaby stopniowa likwidacja „roli państwa w gospodarce”. Wraz z tym biurokracja nie mogłaby nadal przyswajać i rozporządzać podziałem wartości dodatkowej,

${ }^{36}$ Ibidem, s. 427 i 429.

37 „Teorie konwergencji, politol. ogólna nazwa teorii, propagowanych głównie na Zachodzie w latach 60. i 70. XX w., zakładających stopniowe upodabnianie się społeczeństw kapitalistycznych i komunistycznych, którego wynikiem miał być trzeci, pośredni typ ustroju społeczno-ekonomicznego (...) za przejawy procesu konwergencji uznawano podobieństwa między tymi społeczeństwami w zakresie: upowszechniania planowania gospodarczego oraz naukowych metod i technik produkcji i zarządzania, poziomów rozwoju gospodarczego, stylów życia, postępującej dezideologizacji”, encyklopedia. pwn.pl/haslo.php?id=4008849.

${ }^{38}$ Đilas pisał wtedy, że negatywne procesy zachodzące w Związku Sowieckim, związane z powstawaniem i dominacją biurokracji nie są powrotem do kapitalizmu. To są nowe zjawiska, nowe fenomeny powstające na bazie i w ramach socjalizmu, M. Đilas, On New Roads of Socialism..., s. 13. 
wytwarzanej w procesie produkcji. Utrzymując jednakże swoją pozycję i co za tym idzie - rolę w podziale wytwarzanych dóbr, biurokracja „socjalistyczna” upodobniła się do kapitalistycznej. Różnice między nimi zanikają. Pierwotna, a więc „państwowa, socjalistyczna własność” stopniowo przekształca się „w despotyczne władanie biurokracji (...) oraz społeczne i ekonomiczne stosunki, które charakteryzują kapitalizm państwowy; w ogólny, wszechogarniający monopol, w odbudowę i kontrrewolucję szczególnego rodzaju" 39 .

Wspomniana specyfika polega na tym, że w miejsce „dawnego, indywidualnego kapitalizmu”, podobnie jak na Zachodzie, pojawia się państwowa, w istocie kapitalistyczna własność ${ }^{40}$. Własność społeczna, która początkowo musiała mieć państwowy charakter, przetwarza się w swoje przeciwieństwo - „we własność wyłącznie państwową". W rezultacie państwo staje się samodzielną siłą stojącą „ponad społeczeństwem”. Decyduje o podziale wartości dodatkowej, zwalcza „wszelkie wolności i demokrację", wytwarza nieuzasadnione różnice w płacach, powiększa przywileje, początkowo „nieznaczne”, grupy sprawującej władzę, a także wytwarza „zasadnicze, reakcyjne, jakościowe zmiany" w polityce zagranicznej, międzynarodowej, tj. „totalne dążenia do podboju”, do prowadzenia „zaborczych wojen i przetwarzania innych narodów w kolonialne”. Przyswaja wszelkie zasady „prawa monopolistycznego kapitalizmu” sprawiające, że sami „inicjatorzy i protagoniści” takiego systemu stają się jego „posłusznymi sługami i wykonawcami”. „Społeczeństwo (zaś - MJZ) coraz bardziej się rozwarstwia”. Powstają grupy „najemnych pracowników” i warstwa „bardzo dobrze opłacanych, pozbawionych skrupułów, przewrotnych, podstępnych i brutalnych biurokratów państwowo-kapitalistycznych”. Zwycięstwo takich „panstwowo-kapitalistycznych stosunków” w ZSRS „oznacza nie tylko koniec wszelkiego społecznego, socjalistycznego rozwoju, ale i narodziny przeciwieństw i tendencji typowych dla monopolistycznego kapitalizmu”. Taki porządek staje się „totalną negacją" socjalizmu ${ }^{41}$. Choć $\mathrm{z}$ drugiej strony - sugeruje Đilas - nie musi być ostatecznym pogrzebaniem tego systemu. Autor Aktualnych problemów nie neguje swej dawnej tezy z marca 1950 r. o „kryzysie socjalizmu”, jedynie nieco inaczej rozkłada akcenty. Argumentując, że obecny porządek w ZSRS jest równoznaczny z kontrrewolucją, ocenia zarazem, że w długofalowej perspektywie może się stać „wigilią (predvečerje) socjalizmu, choć nie w mniejszym i nie większym stopniu „niż monopolistyczny kapitalizm zachodni", który także ma szanse ewoluować w tym właśnie kierunku ${ }^{42}$. W rezultacie w ujęciu Đilasa oba systemy państwowo-kapitalistyczne, tj. zachodni i sowiecki, aktualnie są w istocie tożsame i mogą takimi pozostać w przy-

${ }^{39}$ Idem, Savremene teme, s. 13-15.

${ }^{40}$ Należałoby powiedzieć, w zgodzie z logiką myśli Đilasa, że jest to własność nowego typu, bo zdominowana nie przez tych, którzy ją posiadają, lub którzy powinni ją posiadać - jak w „socjalizmie", lecz przez tych którzy nią zarządzają, w imieniu nominalnych, formalnych właścicieli, $w$ tym wypadku bez różnicy - w systemie kapitalizmu zachodniego, czy nowego, „socjalistycznego”, który, zdaniem Đilasa, powstawał w ZSRS i w krajach od niego zależnych.

${ }^{41}$ Idem, Savremene teme, s. 15-16.

${ }^{42}$ Ibidem, s. 19-20. 
szłości. Przypominając myśli i rozważania późniejszych „konwergencjonistów”, poglądy Đilasa wyróżniają się przede wszystkim negatywną oceną tych porządków społeczno-ustrojowych ${ }^{43}$.

Analizując stosunki panujące w ZSRS, Đilas już w marcu 1950 r. określał warstwę sprawującą w nim władzę mianem „kasty”44. Obecnie szerzej rozwija i uzasadnia swą myśl w tej sprawie, co będzie istotne m.in. z punktu widzenia jego koncepcji politycznych, poglądów wyrażonych parę lat później w Nowej klasie. Należy tylko zastrzec, że Đilas nigdzie nie przedstawia definicji tej grupy, nie precyzuje, kto znajduje się w jej składzie. W jego ujęciu „biurokracja” jest pojęciem ogólnym, by nie powiedzieć - ogólnikowym. Wiadomo jedynie, że chodzi mu nie tyle o formę rządów czy zarządzania, lecz o osoby, które są u władzy. Z jego opisu trudno byłoby jednakże wywnioskować, czy obok Stalina i jego otoczenia Đilas ma na myśli również podrzędniejszych urzędników, a więc funkcjonariuszy posiadających mniejszy czy wręcz nikły udział we władzy. Tak czy inaczej określa sowiecką biurokrację mianem „kasty”, głównie dlatego, że nie jest ona „homogeniczną klasą”, lecz „hierarchicznie zróżnicowaną” warstwą; „kastą”, niezależnie od faktu, że korzystającą „ze wszystkich - jak pisze Đilas - klasowych, kapitalistycznych przywilejów”, tj. $\mathrm{z}$,uprzywilejowanego, pasożytniczego" udziału w podziale wartości dodatkowej. „W Związku Sowieckim nie ma formalnej, klasycznej własności i stąd nie ma klasy, ale..., ale jako zbiorowy właściciel występuje aparat państwowy", który może mieć tylko „kastowy” charakter. „Przywileje klasowe, a nawet feudalne” sprawiają, że biurokracja występuje „jako jakaś nowa klasa”, podobnie jak nowy wydaje się cały "porządek społeczny” ${ }^{45}$.Taka sytuacja nie zmienia jednakże istoty rzeczy. Istnieje warstwa, która przyznaje i dzieli wartość dodatkową, „sam zaś fakt braku istnienia ścisłej, stabilnej klasy właścicieli (...) nie oznacza zmiany kapitalistycznych stosunków społecznych”. Nie ma żadnego znaczenia, czy wartość dodatkową zagarniają „formalni”, kapitalistyczni właściciele czy „generalny dyrektor jakiegoś kapitalistycznego trustu”. Formy eksploatacji ulegają zmianie, ale „istota rzeczy pozostaje ta sama”. Nie ma klas, ale coraz większe i brutalniejsze są różnice między „kastą kapitalistycznych urzędników i bezpośrednich wytwórców”. Obecne stosunki społeczne w Związku Sowieckim, powstałe pod wpływem polityki biurokratów, stają się hamulcem i najpoważniejszą przeszkodą dalszego rozwoju socjalizmu na świecie i w samym ZSRS. Są symptomem „państwowego kapitalizmu” i jego przedstawiciele, podobnie jak zachodniego, muszą wykorzystywać „pozostałości (? - MJZ) określonego, panującego narodu” i w pierwszym rzędzie sprzyjać uprzywilejowaniu „biurokratycznej kasty tej nacji”, w tym wypadku - rosyjskiej. Zdaniem Đilasa, właśnie taka sytuacja umożliwia biurokracji uzyskanie „ekstraprofitu”, sprzyja rozwojowi nacjonalizmu wielkorosyjskiego, zaostrzaniu kwestii narodowych i potwornemu,

${ }^{43}$ Głównie dlatego, że w odróżnieniu od przedstawicieli tych koncepcji, idee „konwergencyjne” Đilasa wykluczają jakikolwiek rozwój, postęp.

${ }^{44}$ Ibidem, s. 20-21.

${ }^{45}$ Ibidem, s. 21. 
w czasie II wojny światowej, „wyniszczaniu całych narodów (w ZSRS i przez ZSRS MJZ), do czego nie był zdolny nawet niemiecki kapitalizm w czasie rządów Hitlera - za wyjątkiem likwidacji Żydów”. Ostatecznie „kapitalistyczny, monopolistyczny porządek państwowy w Związku Sowieckim nie mógł zapobiec istnieniu narodowych przeciwieństw, charakterystycznych dla monopolistycznego kapitalizmu w ogóle”. Co więcej, „swoją totalnością" sowiecki system „jeszcze je powiększy”” i wyposażył „w najbrutalniejsze formy”, jakie można sobie wyobrazić „w historii współczesnego kapitalizmu”46.

Należy podkreślić, że pisząc o Związku Sowieckim jako państwie kapitalistycznym, Đilas pomija dwa bardzo istotne wyznaczniki tego systemu, niewystępujące w „Kraju Rad”, tj. brak własności prywatnej ${ }^{47}$ i rynku jako zasadniczego instrumentu regulującego procesy gospodarcze ${ }^{48}$. Sprawiające, że dany kraj określamy mianem kapitalistycznego. Podkreśla jedynie znaczenie istnienia najemnych stosunków pracy i wyzysku wynikającego z niesprawiedliwego podziału wartości dodatkowej. Równocześnie twierdzi, że sowieckie państwo kapitalistyczne jest organizmem imperialnym dawnego typu - można by powiedzieć - w XIX-wiecznym stylu. Występują w nim dawne, zanikające na Zachodzie „kolonialno-zaborcze (...) formy”, choć $\mathrm{w}$,»socjalistycznych « uniformach”. Podporządkowane mu kraje środkowo-europejskie są przekształcane „,w despotyczne dyktatury państwowo-kapitalistyczne kolonialnego typu, jak Rumunia, lub półkolonialnego - np. w przypadku Polski”. Ponadto, nie musząc się liczyć z naciskami wywieranymi przez różne warstwy społeczne i poszczególne grupy monopolistyczne, z mechanizmami demokratycznymi, sowieckie imperium, będące w istocie „jednolitym, państwowym monopolem” jest dynamiczniejsze i bardziej zwarte niż zachodnie imperia, z USA na czele. Przynajmniej „tymczasowo” sprzyjają mu również różne „socjalistyczne”, „rewolucyjne”, a nawet „pokojowe" hasła, skrywające jego prawdziwą, imperialistyczną naturę ${ }^{49}$.

$\mathrm{W}$ rezultacie, pisze Đilas, państwo sowieckie z istoty rzeczy musi być przeciwne wszelkiej rewolucji, także jugosłowiańskiej. Przywódcy ZSRS nie myślą o tym, by „ideologicznie i politycznie” pomagać w obalaniu kapitalizmu w tym czy innym kraju i wprowadzać tam system „socjalistyczny”. Dążą tylko do tego, „aby ich armia” wykorzystywała miejscowe ruchy rewolucyjne, podbijała ,jakieś terytorium” i poszerzała „ich własne panowanie”. Kremlowscy przywódcy wykorzystują „każdą rewolucję i demokrację" do rozprzestrzeniania swojej hegemonii. Nienawidzą komunistów jugosłowiańskich, bo są oni „marksistami i rewolucjonistami”. Stąd w historycz-

\footnotetext{
${ }^{46}$ Ibidem, s. 21-23.

${ }^{47}$ Co jest wynikiem wspomnianego przekonania, że w aktualnej fazie rozwoju kapitalizmu nie posiada ona istotnego znaczenia.

${ }^{48}$ Rolę instrumentu regulującego procesy gospodarcze w systemie sowieckim spełnia biurokracja, wywołując zresztą efekty charakterystyczne dla każdego systemu kapitalistycznego, tj. wyzysk i nierówności społeczne. Ponieważ są one istotą kapitalizmu, to brak rynkowej koordynacji procesów gospodarczych oraz prywatna własność, w ujęciu Đilasa i tak tracąca swoje dotychczasowe, tradycyjne znaczenie, nie są koniecznymi wyznacznikami systemu kapitalistycznego.

${ }^{49}$ Ibidem, s. 34-36.
} 
nej perspektywie konflikt między Belgradem i Moskwą był i jest nieunikniony, na pewno nie płytszy i nie łagodniejszy „od konfliktu między pracą i kapitałem, despotyzmem monopolu i proletariacką, plebejską demokracją”. Stalin i jego podwładni oskarżają Jugosłowian o niestworzone rzeczy. Gdy więc mówią o „faszyzmie i podobnych sprawach”, rzekomo dotyczących KPJ, to trzeba im odpowiedzieć: „De te fabula narratur" ${ }^{50}$.

Zdaniem Đilasa, specyfika systemu sowieckiego, w istocie tożsamego z ustrojem mocarstw zachodnich, stała u podstaw powstania dwóch przeciwstawnych bloków polityczno-wojskowych. Autor Aktualnych problemów nie minimalizuje roli USA $\mathrm{w}$ tej sprawie, ale pisze przede wszystkim o sowieckiej. Podkreślając, że gdyby ZSRS istotnie był krajem „socjalistycznym” i prowadził „socjalistyczną politykę zagraniczną", to rozwój sytuacji na świecie poszedłby w innym kierunku. Nie okupując i nie narzucając brutalnych form zależności i eksploatacji krajów środkowoeuropejskich i pozwalając, by „swobodnie rozwijały się jako socjalistyczne”, Moskwa nie wywoływałaby strachu rozwiniętych, kapitalistycznych krajów zachodnioeuropejskich mogących się obawiać, że władze sowieckie mogą im narzucić „nikczemniejsze i brutalniejsze formy eksploatacji” niż „amerykańskie monopole”. Równocześnie „patriotyczne masy” tych krajów mogłyby „rozwijać (...) siły i poprowadzić swoje kraje drogą niezależności i socjalizmu”. Tym bardziej że „propagandowe wrzaski o amerykańskim imperializmie i przekształceniu Europy Zachodniej w amerykańską kolonię nie mogły i nie mogą przesłaniać prawdziwego, kolonialnego i zaborczego oblicza rządu ZSRS”. To właśnie jego polityka umożliwiła powstanie Paktu Północnoatlantyckiego, gdyż „zwyczajni ludzie i małe państwa” mogły w nim dostrzec instrument obrony swej niepodległości. Paktu, bynajmniej nietracącego „agresywnego i imperialistycznego charakteru” ${ }^{51}$.

Ostatecznie, analiza sowieckiego systemu prowadzi Đilasa do wniosku, że powstanie „ogólnopaństwowego monopolu” w ZSRS jest zgodne z działaniem naturalnych, immanentnych praw monopolistycznego kapitalizmu. Widoczne w nim dążenia do wyzysku, głównie w polityce zagranicznej ${ }^{52}$, powstają żywiołowo, wynikają ze stosunków produkcjii ${ }^{53}$, właściwych temu systemowi, stwarzają groźbę wybuchu nowej „niesprawiedliwej” wojny światowej. W żadnym kraju masy ludowe nie mogą być nią zainteresowane, ponieważ nie walczyłyby ani o zwycięstwo „socjalizmu”, ani o powstanie rzeczywistej, narodowej niepodległości. Przeciwnie, muszą łączyć swe siły $\mathrm{w}$ walce przeciw zaborczym dążeniom tych, którzy w danym momencie „swoimi konkretnymi posunięciami” zagrażają "pokojowi na świecie”. Taką postawę wymusza ogólna sytuacja, brak istnienia odrębnych światów, „zróżnicowanych społecznie". Niezależnie od tego, co twierdzą wyraziciele tezy o ich istnieniu, mamy do czynienia tylko z jednym, „przeżartym przeciwieństwami, które można czasowo

\footnotetext{
${ }^{50}$ Ibidem, s. 24.

${ }^{51}$ Ibidem, s. 36.

52 Ibidem, s. 37.

${ }^{53}$ Stosunków działających i rozwijających się żywiołowo, ibidem.
} 
złagodzić, ale nie trwale rozwiązać” $\mathrm{w}$ ramach istniejących, „monopolistycznych stosunków" 54 . W rezultacie, wywody Đilasa prowadzą do wniosku, że właśnie jako przedstawiciele tego świata, USA i ZSRS prowadzą politykę zgodną z własnymi, imperialistycznymi celami; politykę wyrażającą się we wspomnianej walce o strefy wpływów. W takim ujęciu istnienie przeciwstawnych bloków nie rozbija jednolitości świata. A to dlatego, że rządzą nim identyczne, „monopolistyczne” zasady „państwowego kapitalizmu". Jego przedstawiciele dążą do tego samego, tj. do dominacji i niezależnie od wrogości między sobą zwalczają alternatywny świat „socjalizmu”, „komunizmu”. Świat, który dopiero powstaje.

Zdaniem Đilasa, jedynym wyłomem w tym kapitalistycznym, imperialistycznym świecie jest „socjalistyczna” Jugosławia ${ }^{55}$. Być może zupełnie nieświadomie powiela on w istocie dawną, sowiecką tezę o istnieniu jedynego „socjalistycznego" państwa, wówczas Związku Sowieckiego, we wrogim, imperialistycznym otoczeniu. Mając na uwadze „rzeczywistą sytuację na świecie”, wychodzi z założenia, że Jugosławia musi wiązać swoją niepodległość z walką „o socjalizm i socjalistyczny rozwój”. Rezygnacja $\mathrm{z}$ „,socjalistycznej” drogi rozwoju byłaby jednoznaczna $\mathrm{z}$ „ożywieniem kapitalistycznych elementów” w kraju i prowadziłaby „do utraty narodowej niepodległości”. Niepodległość można by utrzymać jedynie w oparciu o „socjalizm”, „socjalizm” w oparciu o niepodległość. Należy więc „porzucić wszelkie iluzje, śmiało patrzyć rzeczywistości w oczy (...), nie »filozofować«", tj. nie prowadzić jałowych dyskusji w sprawie wyższości „tego czy innego systemu (...), tylko rozwijać rewolucyjną praktykę i teorię, wykorzystując (...) wszystkie ekonomiczne oraz inne formy, za pomocą których można przyśpieszyć" realizację tych wartości. W związku z tym należy również „do końca” porzucić te „złudzenia”, które wiążą się z „socjalizmem, pokojem i demokracją" w krajach „wschodniego bloku, z ZSRS na czele" ${ }^{56}$. Tym bardziej że sowieccy przywódcy i teoretycy, w istocie „dogmatycy”, są „nie tylko "rewizjonistami« w teorii, ale i w praktyce” stają się coraz widoczniej „nieprzyjaciółmi marksizmu”. „Zniekształcany i fałszowany” jest on jedynie maską, skrywającą ich „prawdziwe oblicze" ${ }^{57}$. Takie stwierdzenia nie mogą pozostawiać żadnej wątpliwości, gdzie Đilas dostrzegał przeciwników swego kraju i jugosłowiańskiego „socjalizmu” przede wszystkim. Wyrażając w tej sprawie nie tylko własne stanowisko, ale i przywódców Komunistycznej Partii Jugosławii. Niezależnie od swoich rozważań w sprawie „jedności” świata, zdominowanego wszakże, zgodnie z logiką jego wypowiedzi, także przez „imperialistów” amerykańskich.

Ostatecznie, „rozwijanie” wspomnianej „praktyki i teorii rewolucyjnej” w ujęciu Đilasa stawało się koniecznością. Nawiązując do słów wypowiedzianych w marcu 1950 r., stwierdzał on, że „socjalizm” powstaje zarówno w walce przeciw „obalonej

\footnotetext{
${ }^{54}$ Ibidem, s. 37-38.

${ }^{55}$ Ta wyjątkowość Jugosławii logicznie wynika z wywodu Đilasa, twierdzącego, że Związek Sowiecki oraz kraje od niego zależne zdołały wytworzyć u siebie jedynie kapitalizm państwowy w istocie funkcjonujący podobnie jak system polityczny państw zachodnich.

${ }^{56}$ Ibidem, s. 37.

${ }^{57}$ Ibidem, s. 23.
} 
burżuazji (...) jak i przeciw próbom biurokracji, by stać się siłą władającą społeczeństwem”. Ewentualne zwycięstwo „burżuazji” oznaczałoby „restaurację prywatnej własności kapitalistycznej”, biurokracji zaś - „państwowego kapitalizmu”"58. Biurokratyczne tendencje wyrastają „z dyktatury proletariatu”, powodują, że „niegdysiejsi rewolucjoniści przekształcają się w chciwych, pozbawionych skrupułów i ogarniętych megalomanią biurokratów”. Wystąpiło to w ZSRS oraz „w ruchach robotniczych i kompartiach pozostających pod kuratelą KC WKP/b", ale zagraża również dalszemu rozwojowi „,socjalizmu” „u nas”, w Jugosławii. Đilas niedwuznacznie sugeruje, że zwycięstwo „socjalistycznej” biurokracji, użytecznej dla „socjalizmu" bezpośrednio po przechwyceniu władzy, mogłoby w istocie doprowadzić do paradoksalnego, a zarazem perwersyjnego zjawiska, tj. do kontrrewolucji, ponownego i jeszcze większego niż w obalonym kapitalizmie zniewolenia mas ludowych, do powielania „szablonów” występujących w Związku Sowieckim. Biurokratyczne stosunki wyrastają na gruncie zacofania, ale tracą rację bytu w miarę rozwoju sił wytwórczych. Prowadzi on do tego, że państwowo-administracyjne, biurokratyczne metody, jako nieefektywne w tej fazie przekształceń ekonomicznych, muszą zanikać, co ma się wyrażać w stopniowym osłabianiu roli państwa, zapoczątkowaniu jego „obumierania” traktowanego jako proces stopniowego przekazywania zarządzania gospodarką bezpośrednim producentom, a więc - rozwoju samorządności zadekretowanej, choć w istocie tylko teoretycznie w końcu czerwca 1950 roku $^{59}$. Miała ona rzekomo sprzyjać „umacnianiu świadomej (...) roli i faktycznych praw mas (pracujących) w gospodarce”, zgodnie z „jasnym” oświadczeniem samego Tity: „urzeczywistnić stare (w domyśle - marksistowskie, MJZ) hasło: przekazać »fabryki w ręce robotnikom " $" 60$. Zgodnie z gołosłownymi deklaracjami Đilasa takiemu „zwycięstwu sił socjalistycznych” w Jugosławii sprzyjałoby istnienie „niezwykle ważnego, nawet decydującego, subiektywnego czynnika - silnej, jednolitej, bohaterskiej, świetnie zorganizowanej, świadomej celów oraz ideologicznie zwartej, rewolucyjnej partii klasowej”, a więc KPJ. A wokół niej: także „zwartej, świadomej i zorganizowanej masy pracowniczej”' ${ }^{\prime}$. Rozważając zaś tę kwestię w szerszej, światowej perspektywie, Đilas stwierdzi w innym miejscu, że zwycięstwo „socjalizmu” we wszystkich krajach, a więc i w Jugosławii pojawi się w rezultacie dalszego „rozwoju sił wytwórczych (...), kapitalizmu i stosunków międzynarodowych"62.

Ta niezwykle optymistyczna wizja, a także idealizacja jugosłowiańskiej partii jest oczywiście nieprzekonywająca. Đilas nie wyjaśnia, dlaczego by jej przywódcy mieli postępować inaczej niż ich odpowiednicy w Związku Sowieckim, a więc przedstawiciele tamtejszej „kasty” biurokratycznej, lub też z jakich powodów zostaliby

${ }^{58}$ I bidem, s. 41. Takie stwierdzenie nie jest zbyt precyzyjne, biorąc pod uwagę, że we wcześniejszych wywodach Đilas sugerował rozwój sytuacji w państwach kapitalistycznych oraz w ZSRS w kierunku kapitalizmu państwowego.

${ }^{59}$ Ibidem, s. 41-52.

${ }^{60}$ Ibidem, s. 42.

${ }^{61}$ Ibidem, s. 49.

${ }^{62}$ Ibidem, s. 32-33. 
zmuszeni do takiego właśnie, odmiennego postępowania. Trudno byłoby ocenić, $\mathrm{w}$ jakim stopniu jego wynurzenia były wynikiem naiwnej wiary czy pobożnych życzeń, w jakim zaś - jedynie rutynową działalnością propagandową i polityczną. Tak czy inaczej, przeciwstawiając sowiecką rzeczywistość powstającemu, „prawdziwemu” układowi stosunków „socjalistycznych” w Jugosławii, Đilas stwierdza, że zrozumienie „istoty społecznego porządku” i ściśle z nim związanej polityki zagranicznej Kremla wynika nie tylko z przyswojenia „nauk klasyków marksizmu-leninizmu", z porównania sowieckiej rzeczywistości z założeniami i przesłankami teorii marksistowskich. Wyjaśnienie tego zjawiska jest możliwe głównie dzięki poznaniu „niezwykle bogatej praktyki rewolucyjnej (...) innej (niż sowiecka - MJZ) partii i (...) kraju” idącego „odmienną, socjalistyczną drogą rozwoju”. Đilas ma na myśli oczywiście KPJ i Jugosławię

Ostatecznie w pierwszomajowej proklamacji z $1951 \mathrm{r}^{64}$, Đilas podsumował swoje przemyślenia powstałe w rezultacie konfliktu z 1948 roku. Stwierdzając, że narody i główne siły polityczne w Jugosławii muszą dążyć do umacniania i rozwijania „praw obywatelskich”, umożliwienia „masom ludowym” zarządzania państwem i gospodarką, walczyć z „tendencjami biurokratycznymi” i wszelkimi przejawami gwałcenia „naszej socjalistycznej praworządności”. Następnie otwarcie - jak dotychczas - najwyraźniej zasugerował, że Jugosławia staje się jedyną, w istocie, spadkobierczynią bolszewickiej rewolucji z 1917 r., gdyż „wysoko wznosi sztandar demokracji i socjalizmu; sztandar, który dzisiejsi władcy Związku Sowieckiego wdeptali w błoto, pozbawiając masy pracujące wszelkich praw i wolności, prowadząc politykę (podziału - MJZ) na strefy wpływów, wojen, podbojów, ciemiężenia innych narodów. A czynią to po to, by zaspokoić zaborcze, nienasycone apetyty biurokratycznej kasty. Przyznaje ona sobie prawo, rzekomo w imię walki z kapitalizmem, do grabienia i marnotrawienia owoców pracy robotników we »własnym« (sic! - MJZ) kraju jak i w innych"65.

Z perspektywy czasu Đilas oceni, że powyższe określenia były „ilustracją aspiracji i złudzeń, widocznych w naszym myśleniu politycznym”. Podobnie odniesie się do treści swego wystąpienia na IV. Plenum KC KPJ, 3 VI 1951 r. stwierdzając, że jego treść „bardziej wyrażała nadzieję niż rzeczywistą sytuację”66. Potępiając możliwości wyrażania myśli wyłącznie nawet nie tyle przez partię sowiecką, ile samego Stalina, Đilas oświadczy, że takie monopolistyczne zapędy były widoczne również w partii jugosłowiańskich komunistów. Niemniej - obecnie „nasza partia” walczy ze wszelkimi przejawami monopolizmu, także „w dziedzinie ludzkiej myśli”, ponieważ wszelkie próby wprowadzania wyłączności szkodzą nie tylko samej myśli, lecz równocześnie służą „,reakcyjnym siłom” w urzeczywistnianiu innego, „materialnego i społecznego monopolu, wyrażającego się we władaniu ludźmi i płodami ich

${ }^{63}$ Ibidem, s. 39.

${ }^{64}$ Đilas pisze, że pierwszomajowe proklamacje zazwyczaj pisał Tito. Tym razem przywódca ZKJ był jednakże chory i w rezultacie musiał go zastąpić, M. Đilas, Rise and Fall..., s. 278.

${ }^{65}$ Ibidem.

${ }^{66}$ Ibidem, s. 278, 280-281; M. Đilas, Pad nove klase..., s. 111. 
pracy”. Brak możliwości kontroli ludzkiej myśli wyklucza wprowadzenie i utrzymanie takiego „monopolu” oraz właściwych mu „despotycznych i reakcyjnych form panowania"67. Przynajmniej teoretycznie zwalczaniu tego "monopolu” i tych „form panowania” miała służyć decyzja podjęta na Plenum, że kwestie teoretyczne mogą być przedmiotem swobodnych dyskusji ${ }^{68}$.

Mając na uwadze własną wizję „socjalizmu” i szerzej - wizję propagowaną przez najwyższe autorytety polityczne KPJ z Titą na czele, Đilas usiłował przedstawić konkretną drogę urzeczywistnienia rewolucyjnych celów. Ze świadomością, że będzie ona sprzeczna $\mathrm{z}$ dążeniami oraz interesami jugosłowiańskiej masy partyjnej, wielu osobistości rodzimego aparatu władzy różnego szczebla, z zasadami, które w istocie były tożsame, równoznaczne z sowieckimi, oficjalnie potępianymi. Jego wysiłki są widoczne m.in. w serii artykułów opublikowanych w „Borbie” we wrześniu $1951 \mathrm{r}$. pod tytułem Rozważania dotyczace różnych spraw. Wychodząc z ogólnych samorządowych przesłanek i poglądów, które zostały przedstawione powyżej, Đilas skrytykował w nich stanowisko „dogmatyków” skłonnych twierdzić, że władza jest celem samym w sobie i że zdobyta w czasie rewolucji miałaby sprawić, że „socjalistyczne stosunki społeczne" pojawią się automatycznie. Argumentował, że ich wprowadzenie „wymaga dialektycznego myślenia”, „dialektycznego przeskoku”, tj. odejścia od dyktatury proletariatu, zaniku władzy. Dopiero wtedy mogłaby nastąpić „faktyczna zmiana stosunków społecznych". Sama w sobie bowiem stabilizacja władzy po rewolucji, władzy „proletariackiej”, choć w istocie - biurokratycznej, może być niebezpieczna. Takie rozumowanie - twierdzi Đilas - jest zgodne z myślą Marksa, który przecież nigdzie nie napisał, że po zdobyciu władzy „proletariat” musi zwyciężyć „W walce o wprowadzenie komunizmu”.

Powyższe rozważania Đilasa są dosyć mgliste, ogólnikowe. Nie bardzo wiemy, czy sugerując emancypację, podmiotową rolę szerokich mas ludowych, Đilas ma na myśli zniesienie wszelkiej władzy czy prowadzenie „prawdziwej”, proletariackiej. W przypadku tej drugiej nie wyjaśnia, jak taka władza miałaby wyglądać konkretnie. Sugeruje tylko, że wykorzystanie „dialektycznego myślenia” umożliwi zrozumienie, $w$ jaki sposób można zapobiec rządom biurokracji. Walka z nią jednakże jest trudna, bo nawet zdaniem przeciwników tej warstwy zagraża wzmocnieniem „reakcji”, powrotem jej rządów, to zaś z kolei umacnia wrogie, niepożądane i zwalczane postawy kominformowskie, a więc - sprzyja władzy stalinowskich biurokratów ${ }^{69}$. Đilas nie pisze tego otwarcie, ale wyraźnie daje do zrozumienia, że „koło się zamyka” i że ta swoista pułapka utrudnia "dialektyczną" walkę z przeciwnikami "prawdziwego" socjalizmu $\mathrm{z}$ dwóch przeciwstawnych obozów politycznych.

Niemniej we wspomnianych artykułach Đilas atakuje obie strony, zarówno partyjnych „dogmatyków”, jak i „reakcyjne”, „dekadenckie” siły burżuazyjne. Pisze, że

${ }^{67}$ Ibidem, s. 280-281, 111.

${ }^{68}$ Decyzja ta miała być podjęta pod wpływem idei i przemyśleń Milovana Đilasa, zob. A. Đilas, Hronologija života i rada Milovana Đilasa, http://djilas.info/HRONOLOGIJA/hronologija.html, s. 6-7.

${ }^{69}$ The National Archives, F.O. 371/95586, Southern Department, Yugoslavia, s. $1 \mathrm{n}$. 
decyzje IV. Plenum umożliwiają mu swobodę dyskusji, walkę o urzeczywistnienie własnych idei, aż do zwycięskiego końca. W odróżnieniu od ZSRS Jugosławia wybrała prawdziwą drogę rewolucji i „budowy socjalizmu”. Praktyczne działania $\mathrm{w}$ tym kierunku muszą iść w parze z poszukiwaniami teoretycznymi, intelektualnymi, wynikającymi z analizy dzieł Marksa - głównie Kapitału - a także Engelsa i Lenina. Należy „wykazać światu, że materializm jest silniejszy od idealizmu (...), socjalizm zaś od kapitalizmu". Główną trudnością jest przełożenie ogólnych sformułowań marksistowskich na konkretne twierdzenia i wyszukanie odpowiedniej liczby osób pozbawionych „kominformowskiego” wykształcenia będącego intelektualną podporą „socjalistycznej” biurokracji. Obecna sytuacja sprzyja jednakże „nowym ideom” i „nowym koncepcjom”70. Będą one służyć sprawie rewolucji, zwycięstwu „socjalizmu”. Obok marksizmu główną podstawą edukacji elit, prowadzących masy do tego zwycięstwa, musi być szeroko pojęta humanistyka ${ }^{71}$. Właśnie tylko takie ogólne, wyższe wykształcenie umożliwi realizację zadań współczesnego społeczeństwa zmierzającego do „socjalizmu”. Na tej drodze należy zwalczać przede wszystkim dogmatyczne myślenie i skłonności do bezkrytycznego „cytowania”, bezkrytycznej lektury, w domyśle - dzieł „klasyków”.

Z treści powyższych artykułów wynika, że pisząc o znaczeniu wszechstronnej edukacji w procesie rozwoju „socjalistycznych” stosunków społecznych, Đilas w istocie rezerwuje ją dla elit. A to dlatego, że wykształcenie i wychowywanie mas ludowych ma na celu ukształtowanie jedynie prostej, „typowej osobowości rewolucyjnej”. Świadomej zagrożenia stwarzanego przez „nowego wroga klasowego”, tj. biurokrację. „Prawdziwy” komunista musi być antysowiecki, przygotowany na wszelkie chwyty, podstępy, pułapki i zasadzki stwarzane przez biurokratów i „dogmatyków”, na ich oszustwa. Stanowczo musi walczyć z korupcją, przywilejami i pogardą dla pracy fizycznej. Musi wiedzieć, że ludzie są „postępowi” lub „reakcyjni” zależnie od tego, czy dążą do przywłaszczenia czy przekazania własności dodatkowej społeczeństwu. To ostatnie stwierdzenie wynika logicznie z sygnalizowanego już przekonania Đilasa, typowego zresztą dla marksizmu, że przywłaszczanie wartości dodatkowej, powstającej w procesie produkcji, jest zasadniczą przyczyną wyzysku społecznego.

W Rozważaniach... Đilas wiele miejsca poświęca potrzebie tolerowania i rozwijania krytycznego myślenia, stwarzania warunków dla krytycznej analizy społeczeństwa, sztuki, literatury. Niewątpliwie było to zgodne z ówczesną linią polityczną i propagandową ZKJ, ale niezależnie od niej oddziaływały tu zapewne także dawne, niewygasłe zainteresowania tego polityka i teoretyka sztuką oraz literaturą, jego osobiste aspiracje artystyczne i literackie. We wspomnianych artykułach Đilas stwierdza, że w obecnej sytuacji krytyka nie może dotyczyć jedynie formalnych, estetycznych wartości dzieła, $\mathrm{z}$ drugiej zaś strony nie może być tylko instrumen-

${ }^{70}$ Ibidem, Appendix; Analysis of Djilas's Five Articles in „Borba”, September 1951: Freedom of Criticism also for Marxists and Communists in the F.P.R.Y.: The Duties and Part of Scientific Workers in the F.P.R.Y., s. 2.

${ }^{71}$ Ibidem, The Obligation of Communists and Progressive People to Learn: Whence and How They Can Do So, s. 2-3. 
tem partyjnej polityki. To ostatnie, implikujące pomijanie wartości artystycznej przy ocenie, byłoby sprzeczne z zasadami „dialektycznego materializmu"72, tolerowaniem swoistego „żdanowizmu”73. W rezultacie wszelkie analizy, oceny i krytyki różnorodnych dzieł sztuki nie mogą być wynikiem „dogmatycznego" podejścia ani jakichkolwiek przejawów „dekadencji”. W ujęciu Đilasa ta ostatnia wiąże się zresztą nie tyle, a w każdym razie - nie tylko z oceną, ile charakterem tych dzieł. Wynika $\mathrm{z}$ „materialnego” (? - MJZ), społecznego i moralnego rozkładu klas rządzących. Na Zachodzie jest widoczna głównie we Francji i ujawnia się w poszukiwaniach nowych form artystycznych, wyrażających jednakże ucieczkę twórców od uciążliwości społecznej rzeczywistości w świat wewnętrznych przeżyć osobistych. Istotą zaś sowieckiej „dekadencji” jest całkowita eliminacja nowych form artystycznych przedstawiających rzeczywistość społeczną. Sowieccy artyści posługują się tylko starymi, znanymi środkami artystycznego wyrazu ${ }^{74}$. Taka postawa jest symptomem obawy „kasty” rządzącej w ZSRS, że dzięki nowym formom uciemiężone masy mogłyby poznać ciemne strony życia w tym kraju i reagować sprzecznie z jej interesami.

Ostatecznie, podkreślając pozytywną rolę życia umysłowego, literatury i sztuki, krytyki i dyskusji z punktu „właściwego”, jak można by powiedzieć, „,budownictwa socjalistycznego", Đilas stwierdza, że Jugosławia musi być otwarta na idee docierające ze świata zewnętrznego, ale nie może ich bezkrytycznie przyjmować, zarówno tych ze Wschodu, jak i Zachodu. Odrzucając izolację, musi zachować własną niezależność, jak wynika z kontekstu - swobodnego wyboru i oceny zagranicznych wytworów życia umysłowego i artystycznego.

Wydaje się, że poglądy wyrażone w Rozważaniach... istotnie uzasadniają ocenę, iż jak inni teoretycy partyjni Đilas starał się rozwikłać dylemat „każdej dyktatury, która usiłuje nią być i nie być równocześnie”. $Z$ walnym udziałem Đilasa przywódcy KPJ stwarzali wówczas warunki umożliwiające istnienie „ograniczonej wolności”, głównie w dziedzinie kultury, sztuki, możliwości wypowiedzi. Z myślą, że odpowiednie wykształcenie, siła intelektualna partyjnych elit przyczyni się do zwycięstwa marksizmu w wersji antystalinowskiej, , antyżdanowowskiej”, a więc zgodnej z zasadami „dialektycznego marksizmu” - tak jak go wówczas jugosłowiańscy przywódcy partyjni rozumieli i przedstawiali. I to zwycięstwa nie tylko nad „dogmatykami” i „biurokratami” na Kremlu, ale również własnymi, rodzimymi członkami KPJ, oficjalnie wyrazicielami jej linii politycznej, ale w jakiejś liczbie przynajmniej „ukrytymi kominformowcami”, którzy nie potrafią zrozumieć, „dlaczego stalinowska interpretacja marksizmu, a w konsekwencji - ogólna polityka sowiecka" uległa wypaczeniu i nie może być wzorem do naśladowania. „Artykuły Đilasa wykazują, że władcy dzisiejszej Jugosławii” usiłują pogodzić „pewną dozę wolności (...) z autorytarną koncepcją państwa”. Niewątpliwie „szczerze” chcą znaleźć jakieś „rozwiąza-

\footnotetext{
${ }^{72}$ Ibidem, The Obligation of Communists..., s. 3; Literary and Artistic Criticism in General: Decadence and the Need to Seek New Ways, s. 4.

${ }^{73}$ Od nazwiska Andrieja Aleksandrowicza Żdanowa (1896-1948), kierującego i nadzorującego sprawy sowieckiej ideologii i kultury z ramienia KC WKP/b.

${ }^{74}$ Ibidem, Decadence in its Special Form: Soviet and pro-Soviet Dogmatism, s. 4-5.
} 
nie”, ale nie można by stwierdzić, że się do niego zbliżają. „Szkoda (...) że niewątpliwa, analityczna inteligencja Đilasa, Pijade" oraz innych partyjnych teoretyków jugosłowiańskich nie służy „egzegezie ich pism świętych”; nie służy wykazaniu, że marksistowska, XIX-wieczna interpretacja problematyki ekonomicznej, społecznej i politycznej jest już „przestarzała” - niczego nie wyjaśnia, niczego nie tłumaczy ${ }^{75}$.

Sugerowane wyżej przywiązanie Đilasa do marksizmu, zarówno jako teorii społecznej, jak i metody badań uwidoczniło się w jego rozważaniach dotyczących próby zdefiniowania biurokracji jako warstwy. Zastanawiając się, czym ona jest w istocie - klasą czy kastą - Đilas stwierdził w kwietniu 1952 r. $^{76}$, że „klasę rządzącą” charakteryzuje pozycja w procesie produkcji oraz stosunek do środków produkcji. Ocenił, że w pierwszym przypadku sowiecka biurokracja „nie różni się znacząco od dawnych klas rządzących", jak one bowiem utrzymuje się z cudzej pracy. Decyduje o produkcji i podziale wartości dodatkowej; „bezpośredni producenci nie mają tu żadnych praw". Natomiast w drugim nie posiada cech charakteryzujących te właśnie grupy społeczne. Przede wszystkim nie jest właścicielką środków produkcji w tradycyjnym sensie. Jej własność jest raczej kolektywna niż indywidualna. W rezultacie „socjalistyczna” biurokracja jest nowym fenomenem społecznym: „czymś, co sprawia wrażenie klasy, choć nią nie jest” lub też - „z pewnego punktu widzenia jest, $\mathrm{z}$ innego zaś nie jest klasą". Ponadto Đilas podkreśla swoisty sposób samoodnawiania, procesu reprodukcji tej warstwy nie jako „zbioru indywidualności” czy też pozycji, jakie dziedziczą jej potomkowie. Biurokracja bowiem nie jest żadną zamkniętą grupą. „Podlega uwiecznieniu jako ciało”, w którego składzie znajdujemy osoby „z jej własnych szeregów, ale również spośród chłopów i robotników”77.

W tej sytuacji pewne zdziwienie musi wywoływać określenie biurokracji mianem „kasty”. Wynika to z faktu, że Đilas apodyktycznie i niefrasobliwie stwierdza, że zasadniczą cechą kasty są różnorodne przywileje wynikające ze sprawowanych funkcji ${ }^{78}$. Tymczasem kasta najczęściej jest definiowana jako grupa zamknięta, dziedziczna, endogamiczna ${ }^{79}$, „oddzielona od innych szczelnymi przegrodami społecznymi, uświęconymi zwyczajem, prawem albo religią" ${ }^{\circ 0}$. Posiada więc cechy,

\footnotetext{
${ }^{75}$ Ibidem, F.O. 371/95586, Southern Department, Yugoslavia, s. 1-7.

${ }^{76}$ M. Djilas, Class or Caste?, [w:] idem, Parts of a Lifetime, red. M. and D. Milenkovitch, New York, London 1975.

${ }^{77}$ Ibidem, s. 174-175. Parę miesięcy wcześniej, we wrześniu 1951 r. Đilas również argumentował, że „socjalistyczna”, w tym wypadku sowiecka, biurokracja nie może być uznana za klasę społeczną, jak pisał - „w pełnym marksistowskim znaczeniu tego słowa, ponieważ nie mieści się w żadnej »historycznej perspektywie «". Takie określenie nie jest zbyt precyzyjne, tym bardziej, że Đilas podkreśla wykazywanie przez tę grupę społeczną „wszystkich najgorszych właściwości dawnych klas wyzyskujących". The National Archives, F.O. 371/95586, Southern Department, Yugoslavia, Appendix: Molotov in Warsaw: the Spiritual Misery of Bureaucracy, s. 5.

${ }^{78}$ M. Djilas, Class or Caste?, s. 175-176.

${ }^{79}$ Od pojęcia endogamia, oznaczającego „zwyczaj zezwalający na małżeństwo jedynie wewnątrz danej grupy społecznej, szczepu, rodu, kasty, klanu”, zob. W. Kopaliński, Słownik wyrazów obcych i zwrotów obcojęzycznych $z$ almanachem, Warszawa 2000, s. 151.

${ }^{80} \mathrm{Ibidem}$, s. 256; zob. także Kasta, pl.wikipedia.org/wiki/Kasta.
} 
które Đilas odrzuca (zamknięcie) albo o których nie pisze. Na marginesie można by zaznaczyć, że ogólne wywody Đilasa w sprawie właściwości klas społecznych, tradycyjnie, po marksowsku (marksistowsku) rozumianych także mogłyby wzbudzać pewne zastrzeżenia. Wydają się niepełne i nieprecyzyjne ${ }^{81}$.

Należałoby jednakże stwierdzić, że powyższe nieścisłości i zastrzeżenia nie mają większego znaczenia. Przede wszystkim dlatego, że wyraźne predylekcje badawcze, analityczne Đilasa i tak ściśle związane z ogólną linią polityczną oraz ideologiczną przywódców KPJ, w tym wypadku szczególnie ustępują miejsca pragmatyce, potrzebie udowodnienia, że biurokracja jest zjawiskiem subiektywnym, przypadkowym. Zjawiskiem, które może, ale nie musi wystąpić, któremu u siebie Jugosłowianie mogą zapobiec. W rezultacie należy dążyć do tego, by jakiekolwiek określenie nie implikowało nieuchronnej konieczności historycznej, społecznej. Dlatego Đilas napisze, że „gdyby biurokracja była nową klasa (podkr. MJZ)”, to jej zwycięstwu nie można by zapobiec. A to dlatego, że wszelkie klasy są wynikiem „nieuniknionych procesów społecznych"\$2.

Błędne, klasowe potraktowanie biurokracji sprawiłoby, siłą rzeczy, że walka z nią byłaby „daremnym, utopijnym wysiłkiem (...) my” zaś „komicznymi, reakcyjnymi figurami”. Skoro jednakże „biurokracja nie jest klasą, a tylko reakcyjną, antysocjalistyczną tendencją, która pojawia się w okresie przejścia od kapitalizmu do komunizmu, to walka z nią ma charakter postępowy i rewolucyjny”. Z faktu, że biurokracja pojawiła się w jakimś państwie, np. w Związku Sowieckim nie wynika, że wystąpi wszędzie, w „innych krajach, w których obiektywne i subiektywne okoliczności są odmienne” i powodują, że „socjalistyczne tendencje” przeważają. Ze zwycięstwa biurokracji we własnym kraju Stalin wyciągnął błędny wniosek, że było ono symptomem działania „ogólnego prawa rozwoju społecznego”, on zaś osobiście - niemalże jego „boskim” wcieleniem, „inkarnacją” „obiektywnego” istnienia biurokracji, niezależnie od faktu, że taka „obiektywność” jest sprzeczna z naukami „klasyków”. Wierząc jednakże w biurokratyczne, rzekomo „obiektywne” procesy, Stalin spodziewa się, że nieuniknione zwycięstwo biurokracji, potwierdzone wydarzeniami w ZSRS, „spowoduje obalenie kierownictwa Jugosławii i wprowadzi "porządek"” w tym kraju. Zdaniem Đilasa, jednakże o dalszym biegu wydarzeń w jego ojczyźnie zadecydują nie biurokratyczne konieczności, historyczne i społeczne determinizmy ${ }^{83}$, lecz „potęga klasy robotniczej i świadome siły socjalizmu (...) teoria

\footnotetext{
${ }^{81}$ Uderza w nich m.in. brak spostrzeżenia, że w odróżnieniu właśnie od kasty, klasa jest grupą stosunkowo otwartą. Warstwą społeczną, do której można wejść dzięki własnym zdolnościom, inteligencji, pracowitości, zapobiegliwości, a także różnym machinacjom, często na pograniczu prawa lub z pogwałceniem prawa, i przeciwnie - wypaść z powodu bankructwa czy też innych, niesprzyjających okoliczności życiowych. Fakt „lepszego” czy „gorszego” urodzenia jest ważnym, ale nie jedynym i nie przesądzającym z góry czynnikiem przynależności do „lepszej” czy „gorszej” klasy społecznej.

${ }^{82}$ M. Djilas, Class or Caste?, s. 176. Mając na uwadze tytuł późniejszego, najważniejszego dzieła Đilasa, należy dobrze zapamiętać, że wiosną 1952 r., choćby tylko wspomniane względy polityczne i pragmatyczne nie pozwalały mu używać pojęcia „klasy”, a tym bardziej - „nowej klasy”.

${ }^{83}$ To podważanie poglądów wyrażanych przez Stalina i stalinowską biurokrację oczywiście nie było jeszcze jednoznaczne $z$ odchodzeniem Đilasa od konieczności i determinizmów wyrażanych
} 
biurokracji jako nowej klasy mogłaby służyć jedynie stalinowskim, biurokratycznym dạżeniom (podkr. MJZ). Wprowadzałaby zamieszanie w szeregi proletariatu i wszystkich świadomych bojowników socjalizmu”. A także zabijała ich wiarę „we wspaniałe zwycięstwo socjalistycznych stosunków społecznych"84.

Rozważania w sprawie „nowej klasy”, tu jedynie zasygnalizowane podkreśleniami, są ważnym etapem w ewolucji myśli politycznej Đilasa. Kontrastują z jego poglądami ujawnionymi w przyszłości, po usunięciu go jako czynnego, wpływowego polityka w 1954 roku. Obecnie można by jedynie stwierdzić, że w 1952 r., w czasie dyskusji z innymi teoretykami KPJ, opublikowanej na łamach pisma „Komunist”, Đilas potwierdził swoją definicję stalinowskiej biurokracji jako „kasty”"5.

W październiku 1952 r. Đilas opublikował artykuł, w którym ponownie zaatakował sowiecką „kastę”, przede wszystkim zaś jej przywódcę, Stalina ${ }^{86}$. Bezpośrednim powodem było opublikowanie przez kremlowskiego dyktatora rozprawy poświę-

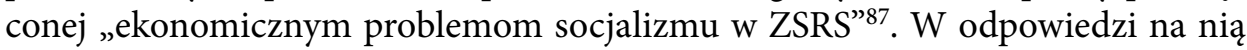
Đilas stwierdził, że jedną z zasadniczych konsekwencji konfliktu z 1948 r. stało się ujawnienie istoty systemu społecznego „Kraju Rad”. W związku z tym zwrócił uwagę, że w dyskusjach, jakie się pojawiły między Belgradem i Moskwą, teoretycy sowieccy ze Stalinem na czele „podkradają” tezy i oceny swoich „najbardziej znienawidzonych przeciwników”, tj. ideologów jugosłowiańskich. Takim praktykom najczęściej towarzyszy całkowita zmiana sensu jugosłowiańskich wypowiedzi, umieszczanie ich w innych kontekstach, świadome zniekształcanie jugosłowiańskiej myśli społecznej i politycznej tak, aby mogła służyć różnorodnym celom Moskwy: politycznym, propagandowym, ideologicznym. Przytaczając liczne przykłady, które mogłyby potwierdzać jego stanowisko, Đilas pisze, że we wspomnianej rozprawie Stalin porzuca np. własną tezę, wyrażoną w 1939 r., iż w ZSRS rzekomo ,już rozpoczęła się budowa komunistycznego społeczeństwa”. Nie wspomina przy tym, że Jugosłowianie odrzucili ją już w $1948 \mathrm{r}^{88}$, zakładając, że państwo sowieckie „nie wyszło jeszcze z państwowo-kapitalistycznego przedpokoju socjalizmu”, że zatrzymało się na tym etapie rozwoju, zgodnie zresztą z prawdziwym sensem „kontrrewolucji", która w nim zwyciężyła. Stalin - twierdzi Đilas - obecnie mówi jedynie

przez „klasyków” z Marksem na czele. Przynajmniej od tej wersji ich poglądów, która występowała w interpretacji Đilasa.

${ }^{84}$ Ibidem, s. 176-177.

${ }^{85}$ Zob. Diskusija izmeđa Stanovnika, Kristla i Đilasa: klasa ili kasta, „Komunist” V-VIII 1952, 3-4. Szczegóły: H. Stys, „Chcemy mieć naród rosyjski za brata. Nie chcemy jego kierownictwa za pana”. Działalność publicystyczna i polityczna Milovana Đilasa $w$ czasie trwania politycznego konfliktu Jugostawia - ZSRR (1948-1953), „Kwartalnik Historyczny” 2010, 2, s. 50-52.

${ }^{86}$ M. Đilas, Staljin se vrti u krug, [w:] idem, Pad nove klase..., s. 112-127.

${ }^{87} \mathrm{~J}$. Staljin, Ekonomski problemi socijalizma u CCCR-y, „Bolszewik”, 18, 1 X 1952.

${ }^{88} \mathrm{Ta}$ ocena Đilasa jest pewnym uproszczeniem. Mimo otwartego konfliktu, rozpoczętego rezolucją Kominformu z 28 VI 1948 r., postawa Jugosławii wobec Kremla oraz ideologii stalinowskiej zmieniała się stopniowo i powoli. W istocie stała się widoczna dopiero na przełomie 1949 i 1950 roku. Szczegóły: M. J. Zacharias, Od stalinizmu do „herezji”..., s. 113-115; idem, Komunizm, federacja, nacjonalizmy..., s. 105 n. 
o powstaniu „zasadniczych przesłanek umożliwiających przejście do komunizmu”. Jednakże w istocie te "przesłanki” prowadzą tylko do ukończenia budowy „cudacznej, państwowo-kapitalistycznej budowli”. Samo zaś „przejście do komunizmu” nie zależy od woli i roli jakiejkolwiek osobistości, nawet Stalina, ale - zgodnie z wyraźną sugestią Đilasa - od powstania obiektywnych warunków, które by taką ewolucję umożliwiały $^{89}$.

W powyższym artykule Đilas przedstawił Stalina jako nieuka, ignoranta niemającego pojęcia o marksizmie, jako osobę, która świadomie wypacza sens, znaczenie i podstawowe założenia nauk „klasyków”. Przytacza jego stwierdzenie, że w „socjalizmie", a więc w okresie przejściowym, nie może być zgodności między siłami wytwórczymi i stosunkami produkcji, ale od siebie dodaje, że taka ocena odnosi się również do „samego komunizmu”. A to dlatego, że wspomniana zgodność oznaczałaby jedynie „stagnację i zamieranie społeczeństwa”. Đilas sugeruje tu, że nie byłoby żadnych sił, które w dialektycznej walce przeciwieństw prowadziłyby, czy precyzyjniej - zmuszałyby społeczeństwa do rozwoju. Stalin nie bierze tego pod uwagę, podobnie jak i faktu, że sprzeczności między siłami wytwórczymi i stosunkami produkcji w okresie przejściowym wynikają z konfliktu między „uspołecznionymi siłami wytwórczymi i biurokratycznymi stosunkami produkcji”, a więc rządami stalinowskiej „kasty” w dziedzinie gospodarki. Do tego dochodzi konflikt „między socjalizmem i nielegalną (...) konspiracją obalonej burżuazji”. Tylko „konkretne warunki walki" zadecydują, która $\mathrm{z}$ tych grup - biurokracja czy burżuazja - może być poważniejszym przeciwnikiem $\mathrm{w}$ dążeniu do „socjalizmu” ${ }^{90}$. Teoretycznie więc Đilas tego nie przesądza, choć jego wywody od $1950 \mathrm{r}$. poczynając, sugerowałyby, że groźniejszym przeciwnikiem jest biurokratyczna „kasta”. Z upływem czasu będzie się skłaniał ku poglądowi, że obok sowieckiej również rodzima.

Zdaniem Đilasa, widomym objawem ignorancji Stalina miał być jego stosunek do takich kategorii ekonomicznych, jak towar, wartość, wymiana towarowa. Twierdzi, że sowiecki przywódca chciałby je „usunąć”, „unieważnić” i doprowadzić do tego, by „centralna władza” państwowa sama zajęła się dystrybucją produkcji. „To są zwyczajne głupoty” - pisze. Nowe stosunki własności nie likwidują bowiem ogólnych prawidłowości ekonomicznych i pojęć, które są z nimi związane. „Takie kategorie jak towar i wartość mogą ulegać zmianie, pojawiać się w nowych formach, wyrażać nowe treści, społeczeństwo (zaś) w ten lub inny sposób może je kontrolować, utrzymywać w ryzach, ujmować w planach, itd., ale nie może ich całkowicie uchylić". To może uczynić jedynie „obiektywny proces produkcji”. Te pojęcia będą istniały dopóty, dopóki będzie wyrażana potrzeba porównywania "jednej pracy z drugą", „wartości tej pracy z inną”. Istnienie tych kategorii, podobnie jak treści, która im odpowiada, nie ma bezpośredniego związku z wyzyskiem. Można go zlikwidować, zmieniając „charakter własności”, sposób podziału wartości dodatkowej, ale to nie prowadzi do usunięcia takich pojęć, jak „towar, pieniądz, wartość, wymiana towa-

\footnotetext{
${ }^{89}$ M. Đilas, Staljin se vrti u krug..., s. $112 \mathrm{n}$.

${ }^{90}$ Ibidem, s. 115.
} 
rowa”. Wraz ze zmianą stosunków własności mogą one stracić „swoją określoną, tj. kapitalistyczną lub biurokratyczną treść i formę", ale będą istnieć do czasu występowania „różnic w podziale pracy”. Tu Đilas jest bardzo lakoniczny, nie pisze, jak zanikanie tych „różnic” wyglądałoby w praktyce ${ }^{91}$.

Szczególną krytykę Đilasa wywołuje stalinowska próba pomniejszenia znaczenia i użyteczności stosowania pojęcia wartości dodatkowej. Zgodnie z własnym, jak sugeruje, marksistowskim podejściem, Đilas dowodzi, że Stalin wbrew intencjom samego Marksa próbuje dowieść, że wspomniana kategoria może się odnosić tylko do systemu kapitalistycznego. W rezultacie Đilas podważa stwierdzenia sowieckiego przywódcy twierdzącego, że „władza” i rozporządzanie środkami produkcji przez klasę robotniczą wykluczają możliwości istnienia wartości dodatkowej, gdyż „W naszych warunkach” to, co wiąże się z tym pojęciem służy nie uprzywilejowanej grupie, lecz szerokim rzeszom społecznym, zaspokaja ich różnorodne potrzeby.

W ujęciu Đilasa takie stanowisko jest szczególnie wyrazistą próbą zanegowania istnienia obiektywnych prawidłowości ekonomicznych, niezależnych od charakteru każdego ustroju: niewolniczego, feudalnego, kapitalistycznego „czy komunistycznego". W każdym z nich występuje wartość dodatkowa, wartość produktu. Bez nich żadne społeczeństwo „nie mogłoby wypracować rozszerzonej reprodukcji i w związku z tym rozwijać się i egzystować”. Nie ma żadnego „burżuazyjnego” ekonomisty kwestionującego istnienie „wartości dodatkowej, wartości produktu, ponieważ one istnieją i muszą istnieć niezależnie od stosunków społecznych”. Można by tylko stwierdzić, że w systemie kapitalistycznym są one głównym środkiem eksploatacji - poprzez przywłaszczanie przez prywatnego właściciela. Niemniej twierdząc, że „sztucznie” wiąże się je „z naszymi, socjalistycznymi stosunkami”, Stalin sugeruje, że dla ZSRS najkorzystniejsze byłoby ich „usunięcie”. To dążenie do negacji występowania $\mathrm{w}$ „socjalizmie” różnych kategorii ekonomicznych oraz treści, która im odpowiada, w ujęciu Đilasa staje się jedną ze szczególnych cech rozumowania sowieckiego dyktatora. Niezgodnego z twierdzeniami Marksa, który bynajmniej nie negował, nie kwestionował dorobku swoich wszystkich - jak można by powiedzieć - „burżuazyjnych” poprzedników. Tytułem przykładu Đilas podaje, że kategorię wartości dodatkowej twórca materializmu historycznego zaczerpnął od wybitnego ekonomisty brytyjskiego, Davida Ricardo (1772-1823).

Đilas pisze, że wywody Stalina w sprawach gospodarczych świadczą o jego „głupocie”, o nieznajomości „nie tylko marksistowskiej, ale i każdej innej ekonomii politycznej”. Równocześnie ocenia, że wszelkie dążenia do „usunięcia” przez niego obiektywnych pojęć, odnoszących się do każdego społeczeństwa, są próbą ukrycia faktycznej rzeczywistości społecznej w ZSRS. Pomijanie tych pojęć, głównie wartości dodatkowej, ma służyć zatarciu śladu „kto i jak dzieli” tę wartość w „Kraju Rad”. W tych warunkach „głupotę i niewiedzę” Stalina trzeba traktować głównie jako „»użyteczne« narzędzia” jego polityki ${ }^{92}$, skrywającej fakt, że zasadnicze prob-

\footnotetext{
${ }^{91}$ Ibidem, s. $116 \mathrm{n}$.

${ }^{92}$ Ibidem, s. 120.
} 
lemy „kapitalizmu, socjalizmu, demokracji (...) aż do komunizmu” wiążą się z tą „diabelską, oporną wartością dodatkową". Od tego, kto, w jaki sposób i w jakim celu nią dysponuje zależy charakter społeczeństwa. „Usuwając” ją z sowieckiej rzeczywistości, Stalin występuje jako „skrajny reakcjonista” zwalczający socjalizm i jako „najkonsekwentniejszy ideolog państwowego kapitalizmu”. A więc systemu, w którym negowana, ale przecież wytwarzana wartość dodatkowa pozostaje w dyspozycji biurokracji, co nota bene prowadzi do zahamowania rozwoju sił wytwórczych, do stagnacji społeczeństwa ${ }^{93}$.

O właściwym, antysocjalistycznym charakterze polityki oraz ideologii Stalina świadczy jego stosunek do własności społecznej. Kremlowski dyktator utożsamia ją z państwową. Dostrzega także istnienie własności grupowej, tj. tej, którą dysponują kołchozy. Niemniej zgodnie z jego dążeniami stopniowo i ona zostanie przekształcona w „społeczną”, tj. państwową. Jako teoretyk oraz ideolog państwowego kapitalizmu Stalin konsekwentnie zmierza do poszerzenia władzy biurokracji w ZSRS i państwach przezeń kontrolowanych ${ }^{94}$. Fałszowanie istoty własności w Związku Sowieckim, podobnie jak „usuwanie” wspomnianych pojęć ekonomicznych, służy temu samemu celowi politycznemu.

Obok „głupoty” i „nieuctwa” oraz kontrrewolucyjnej, reakcyjnej roli Stalina, Đilas zwraca uwagę na arbitralny, apodyktyczny charakter jego sądów, ocen i twierdzeń, które nie mają nic wspólnego z marksistowską metodą badań charakteryzującą się obiektywizmem i determinizmem w analizie zjawisk społecznych, gospodarczych, politycznych i ustrojowych. Metodą, która woli i działaniu jednostki pozostawia skąpe pole manewru. W ujęciu Đilasa sowiecki przywódca jest „subiektywnym idealistą”, i to w "najgorszym, najordynarniejszym sensie tego słowa”. W związku z tym jego tezy i założenia, rozpatrywane z punktu widzenia „socjalizmu”, świadczą, że Stalin nieuchronnie „kręci się wokół własnej osi”, że pozostaje w „kręgu” spraw, na które nie znajduje właściwych odpowiedzi. O takiej sytuacji mogą świadczyć chociażby jego odpowiedzi na niektóre, bardzo istotne pytania, np.: „kto ochroni społeczeństwo - i to socjalistyczne! - przed ewentualnymi błędami kierownictwa, przed tym, że te błędy nie doprowadzą do społecznych scysji? Do konfliktów między siłami wytwórczymi i stosunkami produkcji?". Stalin odpowiada, że sprawi to właśnie „»prawidłowa polityka« tegoż kierownictwa!”. A skąd społeczeństwo będzie wiedzieć, że jego polityka jest „prawidłowa”? „Tylko stąd, że ją kierownictwo prowadzi! I to właśnie jest tym (zamkniętym - MJZ) kręgiem" - pisze Đilas ${ }^{95}$.

Tymczasem „socjalistyczne stosunki społeczne" rozwijają się inaczej, w sprzeczności z „subiektywną", ,idealistyczną”, arbitralną postawą Stalina. Przede wszystkim w zgodzie „,ze swobodną grą praw socjalizmu”, „swobodną grą społecznych sił wytwórczych”, „społecznym charakterem produkcji”, rozbiciem wszelkich „okowów”, które te siły wiążą, które pozaekonomicznymi, tj. „państwowymi środkami te siły

\footnotetext{
${ }^{93}$ Ibidem, s. 119 n.

${ }^{94}$ Ibidem, s. 115-116.

${ }^{95}$ Ibidem, s. 118.
} 
i grę" wspomnianych „praw” pętają. W ujęciu Đilasa wyzwolenie tych sił nastąpi wtedy, kiedy „klasa robotników” uzyska prawo kierowania procesami produkcji i decydowania o podziale wartości dodatkowej oraz wartości produktu. To właśnie ona ją wypracowuje, a więc to ona jest ,jedynym, naturalnym i prawomocnym" 96 właścicielem środków produkcji; także dlatego, że uruchamia je „własną pracą". W praktyce musi to prowadzić do ograniczenia roli państwa tak, by stało się ono jedynie „strażnikiem socjalistycznej własności i socjalistycznych stosunków”; musi prowadzić do „wprowadzenia demokracji dla ludzi pracy”. W rezultacie - należy zlikwidować „państwowo-kapitalistyczne stosunki społeczne”, tj. te, które zostały rozwinięte w ZSRS i - zgodnie z wyraźną sugestią Đilasa - wprowadzić jugosłowiańskie, samorządowe. To właśnie one są najlepszą gwarancją przestrzegania „swobodnej gry sił praw socjalizmu”. W tych warunkach „przywództwo” będzie mogło popełniać wszelkie możliwe błędy, prowadzić „nieprawidłową” politykę, ale nie doprowadzi ono do „stagnacji społeczeństwa”. Ponieważ właśnie to społeczeństwo będzie rzeczywistym zarządcą, kierownikiem gospodarki, obsadzając wszelkie stanowiska „utalentowanymi” ludźmi. „Socjalizm i ruch socjalistyczny” przestaną wówczas podlegać „zadekretowanym geniuszom”, którzy są „geniuszami” tylko dlatego, że sprawują „określoną funkcję”. Działając w zgodzie z „obiektywnymi prawami socjalizmu” $i$,,socjalistyczną demokracją" ${ }^{\prime \prime}$, „,sam proces społeczny, samo społeczeństwo" będzie mogło naprawić ewentualne błędy oraz odrzucić nieudolne „przywództwo", wyłaniając „nowe”, „młode”, lepiej przygotowane do sprostania kolejnym wyzwaniom i zadaniom ${ }^{98}$.

Jest rzeczą oczywistą, że w politycznej oraz ideologicznej walce ze Stalinem i jego wizją „socjalizmu” Đilas jedną utopię zastępował kolejną. Idealizowane „społeczeństwo" z „klasą robotniczą" na czele miało zastąpić uprzywilejowaną, zdemoralizowaną i żądną jedynie władzy oraz przywilejów biurokrację, rzekomo lepiej zarządzając gospodarką, unikając „stagnacji” i gwarantując powstanie warunków wszechstronnego rozwoju. Antystalinowska „herezja” niewątpliwie sprzyjała narodzinom nowej ortodoksji, której Đilas był współtwórcą, być może - najbardziej przekonanym w szeregach KPJ. Nie wyklucza to faktu, że jego krytyka stalinizmu była uzasadniona i co najważniejsze - niewątpliwie trafna. To właśnie ona była najsilniejszym punktem jego ówczesnej myśli politycznej i w szerszej perspektywie - jugosłowiańskiego kierownictwa partyjnego i państwowego. Z pewnością trudno byłoby nie zgodzić się $\mathrm{z}$ wyrażoną przezeń tezą, że stalinowski system jest gorszy z punktu widzenia „bezpośrednich wytwórców”, a więc „klasy robotniczej”, mas ludowych, „od najsurowszych form współczesnego wyzysku kapitalistycznego" i że jego przedstawiciele dążą do umocnienia swej władzy w ZSRS i poza granicami tego państwa, co powoduje, że choćby z tych względów starają się przedstawić „kapitalizm” w ciemniejszych bar-

\footnotetext{
${ }^{96}$ Ibidem, s. 119.

${ }^{97}$ Ibidem. Wyraźną słabością tego wywodu jest fakt, że Đilas nie precyzuje istoty i charakteru tej „socjalistycznej demokracji” i „obiektywnych prawd socjalizmu”.

${ }^{98}$ Ibidem, s. 118-119.
} 
wach, niż jest on w rzeczywistości; że mając na uwadze własną władzę starają się odkryć „nowe”, jeszcze gorsze „prawa współczesnego kapitalizmu”. W tym właśnie tkwią korzenie "głupawych bajdurzeń” sowieckiej propagandy, dotyczących tego systemu, w istocie bez jakiegokolwiek związku z rzeczywistością. W żadnym razie nie osłabią one kapitalizmu, nie pomogą tym, którzy go zwalczają. „Mogą tylko oszukać masy”, sugerując im rzekomą „wyższość” ustroju „sowieckiego" nad kapitalistycznym. A przecież ten ostatni jest na tyle niekorzystny dla „proletariatu”, że nie trzeba go na siłę jeszcze bardziej „oczerniać”, prześcigając w krytyce twórców marksizmu. To mogłoby przynieść skutki odmienne od spodziewanych, wywołując zamęt w szeregach „proletariatu”. „Genialny »następca« Marksa, Engelsa i Lenina” nie bierze tego pod uwagę. Podobnie jak faktu, że „zasadnicze prawa współczesnego kapitalizmu nie uległy zmianie: praca najemna pozostaje pracą najemną, zysk - zyskiem, a przeciętna stopa zysku jak istniała tak istnieje nadal”. Niemniej nastąpiły również znaczące zmiany, spośród których Đilas wymienia przede wszystkim aktywną rolę państwa, i to nie tylko jako wyraziciela interesów poszczególnych monopoli, ale jako „»samodzielnego «, państwowo-kapitalistycznego czynnika”. Stalin oraz inni sowieccy „teoretycy” nie piszą i nie wyjaśniają tych przekształceń, bo musieliby odkryć „własną, państwowo-kapitalistyczną istotę” oraz jej „reakcyjny” charakter ${ }^{99}$.

Istnienie tej wstecznej cechy wiąże się z faktem, że w czasie II wojny światowej został rozbity jednolity, światowy rynek gospodarczy. Zgodnie ze stalinowską terminologią powstały wówczas dwa rynki „światowe” ${ }^{100}$ : kapitalistyczny i „socjalistyczny” ze Związkiem Sowieckim, demokracjami „ludowymi” w Europie Środkowo-Wschodniej oraz Chińską Republiką Ludową ${ }^{101}$. W powstaniu takiej sytuacji Stalin dostrzega „największy i najbardziej postępowy” rezultat światowego konfliktu zbrojnego ${ }^{102}$.

Đilas twierdzi, że „światowy rynek" powstał w połowie XIX stulecia ${ }^{103}$. Jego zdaniem, „wszyscy marksiści” - od Marksa do Lenina, a także po śmierci tego ostatniego - oceniali, że istnienie i funkcjonowanie globalnego rynku, a także konsekwencje

${ }^{99}$ Ibidem, s. 122.

${ }^{100}$ Poruszając tę kwestię, Đilas nie wyjaśnia dlaczego oba „rynki światowe” mogły powstać dopiero w czasie II wojny światowej. Zgodnie z logiką jego myśli o rozbiciu „jednolitego rynku światowego” powinno decydować powstanie Rosji Sowieckiej w 1917 r., co nastąpiło - jak widać - w czasie I wojny światowej. Należałoby jedynie dodać, że pisząc o „dwóch rynkach »światowych «”, Đilas ma świadomość, że takie określenie jest nieuzasadnione logicznie, bo „światowy” może być tylko jeden; ibidem.

${ }^{101}$ Ibidem, s. 122-123. Zastanawia fakt, że zarówno w ówczesnych, jak i późniejszych rozważaniach Đilas bardzo mało miejsca poświęca powstaniu ChRL, ich ustrojowi oraz stosunkom ze światem zewnętrznym, głównie z ZSRS. Ponadto nie rozpatruje relacji, zależności, różnic i podobieństw między nowo powstałym ustrojem w Chinach i chronologicznie wcześniejszym systemem stalinowskim. Przede wszystkim kwestii, w jakim stopniu ustrój w ChRL był wytworem stalinizmu, w jakim zaś własnym, oryginalnym tworem, zarówno w 1949 r., jak i w późniejszych dziesięcioleciach.

102 Ibidem, s. 123.

${ }^{103}$ Ibidem. Đilas dodaje, że jego powstanie nastąpiło „na określonym stopniu rozwoju sił wytwórczych”. Takie określenie niewątpliwie jest trafne, ale zbyt ogólnikowe, by cokolwiek wyjaśnić. Podpierane autorytetem Marksa oraz innych „klasyków” poglądy, że nowy, światowy rynek przełamuje narodowe granice, rozwija i wyprowadza z izolacji „siły wytwórcze”, wydają się ograniczone, mocno przesadzone w świetle obecnej, XXI-wiecznej globalizacji. 
przezeń wywoływane były świadectwem postępu, jaki się dokonywał dzięki ówczesnemu kapitalizmowi. Taki rynek przełamywał narodowe granice, umożliwiał działanie sił wytwórczych na wyższym, światowym poziomie, wyprowadzał je z izolacji, zwiększając w ten sposób możliwości ich rozwoju oraz stwarzając trudności na drodze powrotu do uprzedniej sytuacji, co by szkodziło postępowi gospodarczemu i społecznemu zarówno na świecie, jak i w ramach „każdego narodu z osobna”. Światowy rynek stawał się także niezbędnym warunkiem umożliwiającym powstanie, jak wynika z kontekstu rozważań Đilasa - w przyszłości, po upływie pewnego czasu - „proletariackiego internacjonalizmu i rzeczywistego (...) zbliżenia ludów w socjalizmie". Niemniej, skoro taki proces postępował w ramach kapitalizmu i hegemonii gospodarki USA, „wysokiego stopnia rozwoju sił wytwórczych” tego państwa, to musiał nieść ze sobą „wyzysk i ciemiężenie” i w rezultacie - różnorodne próby „odgradzania, izolowania i obrony poszczególnych narodów i narodowych gospodarek" przed wspomnianą hegemonią, eksploatacją i uciskiem. Ostatecznie, w tym dosyć mętnym, nieprecyzyjnym wywodzie ${ }^{104}$ Đilas sugeruje, że wspomniane próby podejmowano głównie po rewolucji w Związku Sowieckim. Jego władze mogły obronić się przed tym swoistym procesem globalizacji i równocześnie zachować swoją „państwowo-kapitalistyczną strukturę i władanie biurokracji” jedynie rozbijając światowy rynek i powiązany z nim „rozwój światowych sił wytwórczych”. W rezultacie „społeczną koniecznością dla dzisiejszego ZSRS” stało się „spuszczenie »żelaznej kurtyny «", coraz większa izolacja od świata zewnętrznego, podporządkowanie sobie krajów Europy Środkowo-Wschodniej oraz agresywna polityka zagraniczna. „Siły społeczne”, które mogłyby skierować proces rozwoju Związku Sowieckiego

${ }^{104}$ Biorąc pod uwagę wspomniany brak precyzji, należy zacytować odpowiedni fragment artykułu Đilasa, i to w oryginale, odstępując $\mathrm{w}$ tym wypadku od zasady tłumaczenia przytoczonych wypowiedzi. „Međutim, treba istaći da se svetsko tržište definitivno formiralo sredinom devetnaestog stoleća, na određenom stupnju razvitka proizvodnih snaga. Svi marksisti - od Marksa do Lenjina i posle njega, smatrali su stvaranje svetskog tržišta i sve ono što ono za sobom povlači (jačanje svih i svakojakih veza među ljudima, rušenja pregrada među nacijama itd.) progresivnim činom kapitalizma i nužnim uslovom samog proletarskog internacjonalizma i stvarnog budučeg zbliženja naroda u socijalizmu. Savremeni stupanj proizvodnih snaga ne samo što neminovno zahteva postojanje svetskog tržišta, jer svako njegovo razbijanje znači vračanje nazad, nego je, u stvari, to tržište podigao na veči stupanj od onog iż devetnaestog veka, naime - doveo je do toga da više nije mogučno izolovano, u okviru jedne nacije, razvijanje proizvodnih snaga, bez štete za razvoj i svetskih proizvodnih snaga i svake nacije ponaosob. A pošto se ovaj proces događa dok još postoje kapitalistički odnosi i pod hegemonijom visokog stepena proizvodnih snaga kapitalističkih SAD, on ne može a da istovremeno ne nosi sobom i eksploataciju i ugnjetavanje, a time i svakojako ograničavanje, izolovanje i odbranu pojedinih nacija i nacijonalnih ekonomija od toga. A odbraniti se od toga procesa i istovremeno sačuvati svoju državnokapitalističku društvenu ljušturu i gospodstvo birokratije, Sovjetski Savez je jedino mogao ako razbije svetsko tržište (i ne samo njega nego i povezan - iako društveno protivrečan - razvitak svetskih proizrodnih snaga)", ibidem, s. 123. Z artykułu Đilasa wynikałoby, iż ZSRS chce równocześnie uniknąć „,wyzysku i uciemiężenia” charakterystycznego dla kapitalizmu i zachować swój państwowo-kapitalistyczny charakter, a ten, zgodnie z jego własnymi wywodami rodzi wspomniane negatywne zjawiska. W rezultacie obie części jego rozumowania nie przystają do siebie. 
„w stronę demokracji i socjalizmu”, okazały się za słabe. Stąd bieg wydarzeń w tym państwie „musiał pójść w tym kierunku w którym poszedł”105.

W takiej perspektywie to nie Stalin i jego podwładni, lecz anonimowe siły społeczne, zdeterminowane poziomem rozwoju, głównie gospodarczego, decydują o kształcie państwa sowieckiego. Doprowadzają do tego, że „obiektywnie ZSRS jest dzisiaj najreakcyjniejszym mocarstwem na świecie”, bo „rozbija światowy rynek” zdaniem Đilasa - zasadniczą przesłankę wszelkiego postępu, rozwoju. Nawiązując do swoich wcześniejszych poglądów, pisze on także, że państwowo-kapitalistyczny charakter ZSRS i jego polityka stają się główną przyczyną powodującą, że obecny konflikt między Wschodem i Zachodem nie może stać się walką o urzeczywistnienie rewolucyjnych ideałów, tj. o wprowadzenie „socjalizmu”, a następnie - „komunizmu" w miejsce pokonanego kapitalizmu. Ten konflikt jest jedynie rywalizacją dwóch bloków politycznych. Jeden z nich, tj. kapitalistyczny z USA na czele, dąży do utrzymania globalnego rynku, by na tej drodze „zapewnić sobie ekstraprofity”, drugi zaś, zdominowany przez ZSRS, wprost przeciwnie, pragnie jego rozbicia, czy precyzyjniej - utrwalenia tego rozbicia, tworząc w ten sposób własny rynek, w domyśle mniejszy, ale zabezpieczający państwowo-kapitalistyczny system sowieckiego państwa. System charakteryzujący się „niskimi płacami, grabieżą ujarzmionych ludów i nierentowną wytwórczością"106.

Đilas twierdzi, że ustrój ZSRS oraz wewnętrzna i zagraniczna polityka tego kraju unieważniają przedwojenną tezę Stalina, wysuwaną w warunkach istniejącego jeszcze „rynku światowego"107, że w praktyce sprzeczności między państwami kapitalistycznymi są większe niż między nimi i Związkiem Sowieckim. W tej sytuacji konflikt między państwami kapitalistycznymi byłby bardziej prawdopodobny niż wojna między nimi i ZSRS. Đilas nie neguje sprzeczności w kapitalistycznym bloku ani faktu, że mogą one doprowadzić do zbrojnego starcia między jego członkami. Niemniej występuje z tezą, że do czasu powstania ${ }^{108}$,jako-tako jednolitego rynku światowego" przeciwieństwa między Wschodem i Zachodem, Związkiem Sowieckim i Stanami Zjednoczonymi będą główną determinantą sytuacji międzynarodowej. Mogą sprawić, że po stronie tego lub innego bloku opowiedzą się „różne państwa”. Sugeruje, że główną przesłanką przystąpienia będą względy praktyczne, bez związku $\mathrm{z}$ ideologią i ustrojami tych krajów ${ }^{109}$. W istocie zgodnie z logiką konfliktu mocarstw, niebędącego starciem „socjalizmu” z kapitalizmem.

Jako marksista Đilas podkreśla w swojej analizie znaczenie czynników gospodarczych, w tym wypadku - sprawę jednolitości oraz rozbicia rynku światowego. Niemniej jego rozważania nie zawsze są przekonywające. Đilas nie precyzuje bowiem, jakie byłyby kryteria, wyznaczniki tej jednolitości. Nie wyjaśnia również, dlaczego

${ }^{105}$ Ibidem.

${ }^{106}$ Ibidem.

${ }^{107}$ Co również w świetle logiki wypowiedzi Đilasa jest tezą co najmniej wątpliwą, zob. przyp. 100.

${ }^{108}$ Mając na uwadze, iż uprzednio Đilas pisał o rozbiciu, to należałoby mówić raczej o „przywróceniu" tego jednolitego rynku.

${ }^{109}$ Ibidem, s. 123-124. 
właśnie wspomniana jednolitość lub rozbicie rynku światowego miałyby decydować o charakterze konfliktu między Wschodem i Zachodem. Logika wywodu Đilasa prowadziłaby raczej do wniosku, że zasadniczą siłą sprawczą tego starcia było wspomniane istnienie swoistego, państwowo-kapitalistycznego ustroju sowieckiego. Jego zdaniem, to przecież właśnie ono miało rozbijać rynek światowy i narzucać charakter tego konfliktu. Jako państwo kapitalistyczne oraz imperialistyczne Związek Sowiecki siłą rzeczy bowiem musiał rywalizować ze swoimi zachodnimi odpowiednikami, także prowadzącymi politykę zgodną z regułami kapitalizmu oraz imperializmu. Identyczna natura polityki i ustroju obu stron ${ }^{110}$ wykluczała jakiekolwiek autentyczne starcie ideologiczne, w którym stawką byłaby sprawa „,socjalizmu”, „,komunizmu" w zgodzie z treścią, jaką tym pojęciom nadał Đilas. Rywalizacja obu wielkich mocarstw mogła i musiała mieć charakter przede wszystkim polityczny, ponieważ Stalin nie walczył „o zwycięstwo i szerzenie socjalizmu na świecie, lecz o powiększenie swojego państwowo-kapitalistycznego imperium i zewnętrzne umocnienie biurokracji" 111 . W tych warunkach oddziaływanie rozbitego lub jednolitego rynku światowego musiało mieć wtórne, drugorzędne znaczenie.

Đilas nie pisze otwarcie, ale wyraźnie sugeruje, że państwowo-kapitalistyczny system Związku Sowieckiego niejako automatycznie wymusza ekspansję zewnętrzną Moskwy. Istnieje możliwość, że nie wystąpi ona jako pierwsza w roli agresora, że „przyczajona” będzie czekać, zgodnie ze swoją tezą, „na rozwój sprzeczności w obozie kapitalistycznym", zadowalając się dotychczasowymi podbojami. Niemniej będzie to jedynie tymczasowa "pokojowa” faza jednej i tej samej polityki Kremla, warunkowanej czynnikami obiektywnymi, głównie „wewnętrzną naturą" ustroju sowieckiego, jego „agresywnym i reakcyjnym charakterem”. „Niskie płace realne, nierentowna produkcja (...) związany z tym system ciemiężenia i eksploatacji mas robotniczych (...) żywiołowy i niepohamowany rozrost biurokracji, biurokratycznej despotii i biurokratycznych przywilejów - wszystko to wyprowadziłoby cały system w ślepą uliczkę, jeśliby jego przedstawiciele nie mogli „łupić innych narodów” oraz prowadzić „,agresywnej i zaborczej polityki”. Ostatecznie, takie wywody mogą prowadzić jedynie do wniosku, że sowiecki imperializm jest groźniejszy niż zachodni, amerykański.

Zdaniem Đilasa, sytuacja wewnętrzna ZSRS, jego polityka zagraniczna, a także „ideologiczny zamęt”, powszechna „stagnacja duchowa”, otwarte „fałszowanie socjalizmu”, nieukrywane szermowanie „rewolucyjnymi i socjalistycznymi ogólnikami” bez żadnego związku z rzeczywistością może świadczyć tylko o tym, że właśnie mamy do czynienia „z początkiem ukrytego (...), niedostrzegalnego kryzysu »sowieckiego «112

${ }^{110} \mathrm{O}$ czym pisał przecież w przedstawionych już Aktualnych problemach.

${ }^{111}$ Ibidem, s. 122.

112 Đilas niekiedy używa przymiotnika „sowiecki”, podając go właśnie w cudzysłowie. Dając tym samym do zrozumienia, że pojęcie „sowiecki” w odniesieniu do ZSRS mającemu jakoby reprezentować „władzę ludu”, nie oddaje w istocie imperialistycznego hegemonistycznego charakteru państwa sowieckiego. Taki charakter jest zasadniczo sprzeczny z jakąkolwiek „władzą ludu”, M. Đilas, Savremene teme, przyp. 1, s. 25. 
systemu"; kryzysu, którego w żaden sposób nie można powstrzymać. Przeciwnie, jego objawy wyrażające się w pierwszym rzędzie w „biurokratycznym kursie” będą się tylko „zaostrzać, poszerzać i pogłębiać”. Sowieccy teoretycy ze Stalinem na czele będą nadal zajmować się „fałszowaniem materializmu i socjalizmu”, ukrywając swoje właściwe cele - reakcyjne, imperialistyczne i państwowo-kapitalistyczne. Ich teorie są "do tego stopnia głupie, nienaukowe, płytkie i dziecinne, że człowiek musi zadać sobie pytanie, jak i dlaczego (...) w tym wielkim kraju, w tym wielkim rosyjskim narodzie”, pełnym osobistości obdarzonych różnorodnymi talentami, „,mogło i musiało dojść do takiego upadku ludzkiej myśli, że sam Stalin musi odgórnie wyjawiać takie odwiecznie (znane - MJZ) prawdy jak ta, że język jest środkiem porozumiewania się ludzi” ${ }^{113}$ lub „że nie ma i nie może być produkcji i sił wytwórczych bez społecznych stosunków produkcji”"114.

Obarczając Stalina odpowiedzialnością za stan sowieckiej myśli teoretycznej ${ }^{115}$, Đilas stwierdza, że trudno byłoby go traktować jako marksistę, socjalistę, komunistę. Trudno byłoby się zastanawiać, czy i w jakim stopniu porzucił on ideologię marksistowską oraz sprawę „,socjalizmu”. Jeśliby nawet przyjąć, że „niegdyś” Stalin faktycznie był „marksistą i socjalistą”, to jedynie „prymitywnym, płytkim, wulgarnym”, przede wszystkim ze względów praktycznych. Ten jego "marksizm” i „socjalizm” zanikał w miarę „obiektywnej ewolucji ZSRS od początków socjalizmu i rewolucyjnej demokracji ku państwowemu kapitalizmowi i biurokratyzmowi”. Stojąc na czele tego procesu, Stalin z „marksisty, socjalisty i rewolucjonisty przekształcał się w teoretyka i praktyka państwowego kapitalizmu, w duchowego i bezpośredniego wodza i nauczyciela uprzywilejowanej biurokracji i biurokratycznej dyktatury". I właśnie jako taki teoretyk i praktyk jest osobistością niesłychanie ważną. Głównie dlatego, że „jego teorie i zdolności przyniosły więcej nieszczęścia i porażek socjalizmowi i ruchowi robotniczemu niż wszystkie razem wzięte teorie burżuazyjne od I wojny światowej do dzisiaj”. „Rewolucja Październikowa”, leninowskie ruchy robotniczo-chłopskie, będące w istocie nowymi, demokratycznymi formami władzy, chociaż surowymi i - ogólnie mówiąc - „socjalizm”, spełniały jedynie rolę parawanu umożliwiającego rozwój szkodliwych teorii i procesów w ZSRS. W swoich rozważaniach Stalin często wychodzi od ogólnych, „marksistowskich, socjalistycznych” przesłanek, dając do zrozumienia, że „niedwuznacznie” jest ich wyrazicielem, by skrywając się za nimi, koniec końców wyrazić własne „państwowo-kapitalistyczne i biurokratyczne założenia”. W ostateczności „potrzeby jego reakcyjnej polityki zagranicznej i wewnętrznej” musiały doprowadzić do sfałszowania „rewolucyjnej i socjalistycznej przeszłości (...) marksizmu i socjalizmu”. Biorąc zaś pod uwagę, że każda rzeczywistość się zmienia, sowiecka - w kierunku powiększania tarć między siłami wytwórczymi i stosunkami produkcji, „między państwowo-kapitalistyczną

${ }^{113}$ Aluzja do pracy J. Stalina, W sprawie marksizmu w językoznawstwie, Warszawa 1950.

${ }^{114}$ M. Đilas, Staljin se vrti u krug, s. 124-125.

${ }^{115}$ Zdaniem Đilasa, Stalin musiał pozbawić głosu wszystkich, którzy wykazywali się jakimikolwiek talentami, by jego „przeciętny umysł, wiedza i uzdolnienia” mogły błyszczeć na tle „urzędniczej przeciętności”, ibidem, s. 125. 
nadbudową i socjalistyczną bazą (...) biurokracją i bezpośrednimi wytwórcami”, to naturalną koleją rzeczy można oczekiwać - pisze Đilas - jedynie pogłębienia „bezwstydnego i podstępnego" fałszowania „socjalizmu i marksizmu w ZSRS”. Najnowsza praca Stalina ${ }^{116}$ jest „drogocennym potwierdzeniem” tego właśnie procesu. Skrzętnie ukrywane „"podkradanie « socjalistycznych teorii” powstających w Jugosławii i przedstawianie jako własnych - w porównaniu z jugosłowiańskimi - w zmienionej, zniekształconej formie, ma służyć ułatwieniu fałszowania marksizmu. A także zatajeniu, że w Jugosławii powstaje „coś nowego, socjalistycznego”. Niemniej nieunikniona ewolucja sytuacji wewnętrznej i międzynarodowej zmusi kiedyś kremlowskich włodarzy do bezpośrednich dyskusji z Jugosławią, przedstawianą już nie jako państwo „faszystowskie” ${ }^{117}$, ale jako kraj będący „przedstawicielem oraz wyrazicielem socjalizmu i socjalistycznej myśli”, a więc zaprzeczeniem dzisiejszej Rosji, która z „głównej i wielkiej potęgi rewolucyjnej i socjalistycznej” przekształciła się „,W imperialistyczne i państwowo-kapitalistyczne mocarstwo" 118 .

Istotnym dowodem potwierdzenia „socjalistycznego” charakteru Jugosławii miał być przebieg, dyskusje i postanowienie zapadłe w czasie VI Kongresu KPJ w dniach 2-7 XI 1952 r. w Zagrzebiu ${ }^{119}$. Przywódcy jugosłowiańscy przedstawiali się wówczas jako jedyni prawowici spadkobiercy Października 1917 roku. Takie akcenty ujawniły się wyraźnie w przemówieniu Tity z 3 listopada, łącznie z totalną krytyką wewnętrznej i zagranicznej polityki Moskwy ${ }^{120}$. Wtórował mu Đilas, który, zdaniem Dedijera, „wygłosił wtedy być może najlepsze przemówienie w swoim życiu” ${ }^{121}$. Oświadczając, że choć „duch Rewolucji Październikowej” i „genialnej myśli Marksa, Engelsa i Lenina” został „stłamszony w Związku Sowieckim przez kontrrewolucyjną biurokrację i fałszerzy marksizmu, socjalizmu i Października", to pojawił się, podobnie jak myśl marksistowska, „w innych warunkach”, w postaci „,nowego, ożywczego blasku w naszym kraju”. Żyje i rozwija się „w nieustraszonej, rewolucyjnej, proletariackiej, plebejskiej postaci towarzysza Tity (...) w naszej rewolucji, naszych radach

${ }^{116}$ Ściślej mówiąc, chodzi o dwie wspomniane prace dotyczące ekonomicznych problemów w ZSRS oraz roli marksizmu w językoznawstwie.

${ }^{117}$ Co najpełniej uwidoczniło się w reakcji Kominformu w listopadzie 1949 r., zob. Bela knjiga o agresivnim postupcima Vlada SSSR, Poljske, Čehoslovačke, Mađarske, Rumunije, Bugarske i Albanije prema Jugoslavije, Beograd 1951, s. 164 i n. Tekst redakcji w języku rosyjskim: Jugoslavska kompartija we własti ubijic i szpionow, [w:] Sowieszczanija Kominforma 1947, 1948, 1949. Dokumienty i matieriaky, red. G. M. Adibiekow i in., Moskwa 1998, s. 701-704.

${ }^{118}$ M. Đilas, Staljin se vrti u krug, s. 125-126.

${ }^{119}$ Zob. M. J. Zacharias, Komunizm, federacja, nacjonalizmy..., s. 139 n.

${ }^{120}$ Zob. J. Broz Tito, Borba komunista Jugoslavije za socijalističku demokratiju, [w:] VI Kongres Komunističke partije Jugoslavije (Saveza komunista Jugoslavije), 2-7 novembra 1952, Stenografska beleška, Beograd 1952, s. 25-48; idem, Sukob izmedu Jugoslavije i SSSR-a - iż referata na Šestom Kongresu SKJ (Zagreb, 3 novembra 1952), [w:] idem, O partiji i ulozi komunista, t. 4, Osvrt na istorijski razvitak KPJ/ SKJ (1919-1940), Beograd 1984, s. 142-151.

${ }^{121}$ V. Dedijer, Izgubljena bitka J. V. Staljina, Sarajevo 1969, s. 434-436. Pod wrażeniem przemówienia Đilasa pozostawał również inny dostojnik KPJ/ZKJ, Svetozar Vukmanović-Tempo, zob. S. Vukmanović-Tempo, Revolucija koja teče, t. 2, Beograd 1971, s. 159. 
robotniczych, naszej partii i dzisiaj w tym miejscu”, władając „naszym Kongresem, tą salą, sercami i duszami nas wszystkich"122. Było to równoznaczne z postawieniem kropki nad i, świadczyło o niezwykle bojowej postawie ${ }^{123}$ potwierdzającej fakt, że konflikt sowiecko-jugosłowiański był wówczas także konfliktem ideologicznym.

Ostatecznie przemówienia Tity, Đilasa oraz innych przedstawicieli partyjnych na Kongresie pozostawały w zgodzie z logiką tego konfliktu i z oficjalnymi, deklarowanymi zmianami metod działania władz. W rezolucji VI Kongresu podjętej 7 listopada głoszono, że partia „nie jest i nie może być bezpośrednim, operatywnym kierownikiem życia gospodarczego, państwowego i społecznego; natomiast poprzez swą działalność polityczną i ideologiczną - a przede wszystkim przez przekonywanie - oddziałuje na wszystkie władze i instytucje w taki sposób, aby przyjęły one linię i stanowisko" partii oraz jej członków ${ }^{124}$.

Takie określenie roli partii szło w parze ze zmianą jej nazwy. Od tej pory będzie ona występować jako Związek Komunistów Jugosławii $(\mathrm{ZKJ})^{125}$. W swoich późniejszych pracach Đilas pisał, że to właśnie on był inicjatorem tej zmiany ${ }^{126}$. Tak czy inaczej, w istocie była ona zgodna $z$ oficjalną, deklarowaną zmianą metod działania. Nowa nazwa nawiązywała do tradycji Związku Komunistów, powstałego w $1847 \mathrm{r}$. z inicjatywy Marksa i Engelsa. Miała być wyrazem powrotu do „prawdziwych, marksistowskich korzeni jugosłowiańskiego ruchu komunistycznego" ${ }^{\prime 27}$. Zastąpienie „partii” „Związkiem” miało również sugerować luźniejsze powiązania członków tej organizacji, miało oznaczać, że nie rezygnując z monopolu władzy, przywódcy

${ }^{122}$ Wystąpienie Đilasa na VI Kongresie, 6 XI 1952 r., [w:] VI Kongres Komunističke partije Jugoslavije, s. 397-399: Dokumenti 1948, red. V. Dedijer, t. 3, Beograd 1979, s. 396-398. Przemówienie Đilasa było przerywane licznymi, długotrwałymi oklaskami oraz okrzykami: „Tito bohater!”. Po stwierdzeniu, że „duch Października” włada „naszym Kongresem, tą salą, sercami i duszami nas wszystkich”, delegaci powstali z miejsc i zgotowali „burzliwą owację”. Trwała ona „kilka minut”. Ucichła „dopiero wtedy kiedy w całej sali rozległa się Międzynarodówka, którą delegaci odśpiewali z widocznym wzruszeniem”, Dokumenti 1948, t. 3, s. 398. W późniejszych wspomnieniach Đilas napisze, że jego matka, która słuchała wystąpienia przez radio, miała oświadczyć, że „nie jest dobrze dla Đido (tak Đilas często był nazywany przez przywódców i członków partii) kiedy jest bardziej oklaskiwany niż Tito", M. Djilas, Rise and Fall, s. 296. Można by stwierdzić, że jeśli ta obawa istotnie się pojawiła, to okazała się słuszna. Znalazła potwierdzenie w przyszłości, choć w zupełnie innych okolicznościach. O przemówieniach Đilasa na Kongresie zob. też. M. J. Zacharias, Komunizm, federacja, nacjonalizmy..., s. 141-142; H. Stys, Milovana Đilasa walka ze stalinizmem, [w:] Bałkany w XX i XXI wieku. Historia - polityka - kultura. Materiały z konferencji „Poznać Bałkany”, Toruń, 29 maja 2009, red. H. Stys i Sz. Sochacki, Toruń 2009, s. 17-18.

${ }^{123}$ Bardzo plastycznie przedstawił ją Dedijer, pisząc, że „cały VI Kongres skręcał się w bojowych spazmach. W czasie jego trwania było coś z atmosfery panującej u Zaporożców piszących list do sułtana; grozili oni pisarzowi najgorszymi konsekwencjami w przypadku pominięcia ich własnych, osobistych obelg miotanych pod adresem władcy znad Bosforu”, V. Dedijer, Izgubljena bitka..., s. 440.

${ }^{124}$ Rezolucija VI Kongresa o zadacima i ulozi Saveza komunista Jugoslavije, 7 novembra 1952, [w:] Jugoslavija 1918-1988. Tematska zbirka dokumenata, red. B. Petranovic i M. Zečevic, Beograd 1988, s. 1037.

${ }^{125}$ Savez komunista Jugoslavije (SKJ).

${ }^{126}$ M. Djilas, Une société imparfaite..., s. 240; idem, Rise and Fall, s. 292.

${ }^{127}$ D. Bilandžić, Hrvatska moderna povijest, Zagreb 1999, s. 342. 
partyjni doszli do przekonania, że w nowych warunkach, po zakończeniu dawnej, podziemnej działalności i ustaniu walki zbrojnej, po zdobyciu władzy, istnienie dotychczasowego, leninowskiego typu partii - monolitycznej, zdyscyplinowanej, scentralizowanej, w pełni zhierarchizowanej - nie odpowiada nowej rzeczywistości, potrzebie budowy „demokratycznego socjalizmu” 128 . W rezultacie, jako czołowy teoretyk partyjny, Đilas będzie wówczas uzasadniać potrzebę porzucenia tego typu partii.

W artykule napisanym w końcu $1952 \mathrm{rr}^{129}$ Đilas stwierdzi, że organizacje polityczne powstają i działają w określonych warunkach historycznych. Dotyczy to również partii robotniczych, przede wszystkim leninowskich, bolszewickich. Nie są one ostoją tradycyjnego porządku, dążą do przemian, przygotowują rewolucje. Muszą więc jednoczyć, kierować całą „klasą robotniczą” w okresie walki o władzę. Zdaniem Đilasa, taka „koncentracja (...) aktywności klasy w rękach partii w czasie rewolucji i rewolucyjnych przemian jest warunkiem zwycięstwa sił socjalistycznych". Naturalną koleją rzeczy przywódcy partii uzyskują dominującą, uprzywilejowaną pozycję, podejmują zasadnicze decyzje, wskazują kierunek przemian. Niemniej po rewolucji taka sytuacja musi ulec zmianie. Przede wszystkim dlatego, że po pokonaniu i usunięciu burżuazji następuje okres budowy zrębów nowego systemu „socjalizmu” - którego „nie wznosi partia, lecz klasa, swoją rolą w obiektywnym, społecznym procesie produkcji”. W tych warunkach, zasadniczo odmiennych, nie ma potrzeby koncentracji wszystkich sił, kierowania nimi przez partyjne przywództwo. Szerokie rzesze ludowe muszą uzyskać swobodę, możliwości samodzielnego działania, wykazania się inicjatywą, umiejętnością zarządzania i kierowania gospodarką ${ }^{130}$. Tylko one bowiem, uwolnione spod panowania „kapitalistów” oraz „opieki biurokracji” mogą „rzeczywiście rozwijać socjalistyczne stosunki i socjalistyczny proces". Musi więc pojawić się swoiste samoograniczenie każdej partii, musi ona zrezygnować z „bezpośredniego” kierowania „wszystkim i wszystkimi”. W przeciwnym razie powstaną możliwości „Zwycięstwa sił biurokratycznych”, zazwyczaj głoszących potrzebę własnego przetrwania w roli obrońcy „socjalizmu” przed jego wrogami, ostatecznie - możliwości triumfu systemu identycznego z tym, który powstał z ZSRS. Rezygnując $\mathrm{z}$ bezpośredniego zarządzania i przywilejów, partia ma stać się swoistym „wychowawcą” "klasy robotniczej”, uczącym i przygotowującym ją do budowy „socjalizmu”; organizacją zachowującą „ideowe” i „polityczne” przywództwo. W rezultacie „partia leninowskiego typu jest tylko produktem rewolucyjnego rozwoju", określonego etapu historycznego. Nie można jej traktować jako „formy klasowej organizacji raz na zawsze ustanowionej” 131 .

Wyżej przedstawiona argumentacja może wzbudzać jednakże pewne wątpliwości. Przede wszystkim sugestia, że przy braku bezpośredniej kontroli „klasa

${ }^{128}$ A. Djilas, The Contested Country. Jugoslav Unity and Communist Revolution 1919-1953, Cambridge Mass., London 1991, s. 176.

${ }^{129}$ M. Đilas, Preživelost lenjinističke partije, [w:] idem, Pad nove klase..., s. 128-137.

${ }^{130}$ Ibidem, s. $128 \mathrm{n}$.

131 Ibidem, s. 131-132. 
robotnicza”, czy ogólniej - szerokie rzesze społeczne - istotnie chciałyby wznosić „socjalizm”, jest bardziej wyrazem pobożnych życzeń niż rzeczywistości. Ponadto niezbyt przekonywające jest twierdzenie, że swoiste „samoograniczenie” partii, jej rezygnacja $\mathrm{z}$ bezpośredniego zarządzania, głównie w gospodarce, byłaby wystarczającą przeszkodą, uniemożliwiającą powstanie biurokracji, „przywilejów”, „,ideologii partii”, „kultu partii”, „kultu przywódcy”, „kultu umacniania partii jako celu samego w sobie" itp. ${ }^{132}$ Źródła tych zjawisk należałoby dostrzegać przede wszystkim w jednopartyjnym systemie rządów, w niechęci do wielopartyjnego, do parlamentaryzmu; we wspomnianym, „politycznym” przywództwie partyjnym. W pomijaniu oczywistego skądinąd faktu, że „wychowawcza” oraz „ideowa” wyłączność partii, nota bene sprzeczna z krytykowanym przez Đilasa monopolem ideologicznym, siłą rzeczy musiała sprzyjać powstawaniu przesłanek, które kształtowały potępiany przezeń „imperialistyczny” i „państwowo-kapitalistyczny” charakter Związku Sowieckiego. W rezultacie można by także dyskutować z tezą, że partia, która się „samoogranicza”, przestaje tym samym nadzorować każde niezależne posunięcie tych czy innych przedstawicieli „klasy robotniczej”; że utrzymując przywilej wyłącznego rządzenia i głoszenia jedynie słusznej ideologii, istotnie może się przekształcić „W swoje przeciwieństwo”, przestając być partią leninowskiego, bolszewickiego typu $^{133}$. Można by powiedzieć, że sugerując potrzebę eliminacji takiej czy takich partii, Đilas nie dostrzega właściwych przesłanek, które istotnie mogłyby sprzyjać takiemu właśnie procesowi.

Ostatecznie jednakże wywody przedstawione w artykule prowadzą Đilasa do wniosku, że leninowskie partie są niezbędnym, ale tymczasowym narzędziem rewolucji. Đilas pisze, że zrozumieli to przywódcy KPJ/ZKJ, czego nie można powiedzieć o władzach ,innych partii komunistycznych”, których ideologia, kadry, system organizacji i metody działania zostały dostosowane do "niesocjalistycznej polityki rządu sowieckiego", nie odpowiadając „konkretnej rzeczywistości wewnętrznej i międzynarodowej”. Nie mając kontaktu z tą rzeczywistością, są one ugrupowaniami „dogmatycznymi, niemarksistowskimi i niesocjalistycznymi". Podobnie jak przywódcy sowieccy, władze tych partii stosują metody sprzeczne z wymogami współczesności, aktualnych potrzeb „socjalizmu” i proletariatu, a więc z naukami samego Lenina, „niezwykle utalentowanego (...), genialnego marksisty i rewolucjonisty”"134 - zgodnie z sugestią Đilasa świadomego potrzeby przystosowania działalności rewolucyjnej do zmiennej rzeczywistości. Potrzeba taka stała się widoczna zwłaszcza po zakończeniu II wojny światowej. To głównie wówczas należało zmienić „taktykę i formy działania”. W rzeczywistości jednakże stało się inaczej. W warunkach podziału świata na imperialistyczne bloki Moskwa wykorzystuje „ruch robotniczy” oraz partie komunistyczne do walki ze Stanami Zjednoczonymi oraz ich sojusznikami. Taka polityka nie ma nic wspólnego z działalnością rewolucyjną, służy jedynie podziałowi

\footnotetext{
132 Ibidem, s. 132.

133 Ibidem, s. 131.

134 Ibidem, s. 132.
} 
w łonie tego ruchu i wykorzystaniu jego części jako przydatnego instrumentu we wspomnianej walce. W rezultacie „despotyczna i hegemonistyczna polityka sowieckiego rządu”, będąca „najpoważniejszą przeszkodą rozwoju socjalizmu”, wymaga stosowania starych metod. Moskwa i partie jej podporządkowane nie mogą stosować nowych, służących „socjalizmowi”, skoro władza sowiecka „definitywnie” (podkr. MJZ) przeciwstawia się „każdemu, istotnie rewolucyjnemu i (...) socjalistycznemu rozwojowi”. Taka polityka siłą rzeczy osłabia czy nawet likwiduje rewolucyjne możliwości różnych partii komunistycznych i równocześnie „wzmacnia niedemokratyczne i wojownicze elementy w państwach kapitalistycznych (...). To, co się wydarzyło i nadal ma miejsce w krajach wschodnioeuropejskich »wyzwalanych" przez armię sowiecką, a także agresywne poczynania ZSRS skierowane przeciw Jugosławii ${ }^{135}$ są zbyt wymowne (...) by można oszukać jakiekolwiek narody". W tych warunkach „reakcyjne elementy burżuazyjne mogły i nadal mogą skupiać masy pod hasłem obrony przed sowiecką agresją”, a także zadawać „ciosy podzielonej klasie robotniczej - głównie we Włoszech oraz we Francji”"136.

Stwierdzenie, że imperialistyczna polityka Kremla jest zasadniczą siłą, hamującą rozprzestrzenianie rewolucji i socjalizmu, skłania Đilasa do pytań o przyszłą taktykę i strategię komunistów. Jego odpowiedzi w tej sprawie są dosyć niejasne i ambiwalentne. Đilas konstatuje postępującą słabość zachodnioeuropejskich partii komunistycznych, także tych najsilniejszych, tj. włoskiej i francuskiej, lawirujących „między kłamliwym patriotyzmem i służbą Moskwie, między rewolucyjną frazeologią i forsowaniem swej roli (...) w parlamencie", czemu towarzyszy zaniedbywanie służby klasie robotniczej „jako całości”, zaniedbywanie walki o jej „rzeczywiste interesy”. Równocześnie jednak Đilas dostrzega, że zmiany społeczne, zdobycze „burżuazyjnej demokracji” są nie tylko, jak w przypadku Wielkiej Brytanii, ,wynikiem specyficznego rozwoju (...) kapitalizmu”, ale i „,uporczywych wysiłków klasy robotniczej”, walczącej o lepsze, humanitarne warunki życia. Zgodnie z przewidywaniami Marksa - pisze Đilas - wzrosła „obiektywna rola klasy robotniczej w procesie produkcji (...), w życiu społecznym rozwiniętych krajów”. Czy można byłoby obecnie wyobrazić sobie jakiegokolwiek „burżuazyjnego polityka”, lekceważącego rzeczywistą siłę i rolę „klasy robotniczej”? W rezultacie należy wykorzystywać „burżuazyjne” osiągnięcia - „demokratyczną dyskusję (...), swobodną agitację" i możliwości propagowania własnych idei. Przede wszystkim zaś tak rozumianą demokrację trzeba chronić przed niepożądanymi wpływami „biurokratycznych tendencji państwowo-kapitalistycznych”, a także nie dopuszczać do tego, by „prywatno-monopolistyczne elementy” na Zachodzie wykorzystały ją "jako instrument swojego władania", służący wyhamowaniu rozwoju, a nawet powrotowi do „dawnych form kapitalizmu” 137 .

Jak pisaliśmy, Đilas silnie krytykował współczesną mu, państwowo-kapitalistyczną formę ustrojową, przede wszystkim tę w wydaniu sowieckim. Niemniej w analizo-

\footnotetext{
${ }^{135} \mathrm{~W}$ rezultacie konfliktu w 1948 roku.

${ }^{136}$ Ibidem, s. 133-135.

${ }^{137}$ Ibidem, s. 135-137.
} 
wanym artykule ocenia, że przejściowo spełnia ona pozytywną rolę. Nacjonalizacja i umocnienie państwowego kapitalizmu są według niego formami bardziej postępowymi niż „tzw. prywatna inicjatywa”, a więc uprzednia, pierwotna forma kapitalizmu, w którym wiodącą rolę spełniała nie biurokracja, lecz właściciele środków produkcji. Chodzi więc nie tylko o to, „przynajmniej w krajach rozwiniętych, by zdobyć władzę na drodze rewolucji - jak w Rosji w czasach Lenina - lecz o to, by wykorzystać istniejące demokratyczne formy w celu przyspieszenia rozwoju w kierunku socjalizmu". Rozwoju zapoczątkowanego wejściem kapitalizmu w fazę kapitalizmu państwowego - „koniecznego, przedsocjalistycznego etapu”, „przedsionka socjalizmu”. Koniecznego, ale nie wiecznego - i co najważniejsze - w ostatecznym rozrachunku sprzecznego z wymogami „socjalizmu”, hamującego jego rozwój. Dlatego socjalistyczny postęp musi być chroniony przed „państwowo-kapitalistyczną despotią i monopolem" przy wykorzystaniu właśnie wspomnianych, demokratycznych form - „walka o demokrację" musi się stać „głównym motywem (...), hasłem i bodźcem każdego, kto faktycznie walczy o socjalizm". Należy być tam, gdzie są robotnicy, rozwijać ich świadomość społeczną i polityczną, wyjaśniać im nowe czynniki rozwoju. W tych warunkach „stare, wąskie, »rewolucyjne « formy organizacji” stałyby się jedynie przeszkodą, zawadą prowadzącą do klęski. Zdaniem Đilasa, rewolucyjne metody działania powinny w istocie polegać na ich porzuceniu, na wynalezieniu i przyswojeniu nowych „na podstawie analizy przemian we współczesnym świecie". Można by nawet zanegować zasadę niezależności organizacyjnej komunistów od „innych ruchów robotniczych”. Mieliby oni jedynie zachować „ideową swobodę walki za swoje przekonania”. Muszą być one „komunistyczne, socjalistyczne”. Należy postępować zgodnie z tym, o czym mówił już Marks, który miał twierdzić - zdaniem Đilasa - że komuniści nie powinni łączyć się w ugrupowania przypominające „inne partie klasy robotniczej”, lecz tylko stanowić „najbardziej postępową część klasy (podkr. - MJZ)”, walczącej i działającej wszędzie tam, gdzie są „robotnicy i robotnicze organizacje". Powinni być ideologami tej klasy, powinni wyrażać interesy ruchu robotniczego ,jako całości” ${ }^{138}$.

Ostatecznie, powyższe poglądy były jednoznaczne zarówno z porzuceniem tradycyjnej, leninowskiej koncepcji rewolucji, jak i leninowskiego, bolszewickiego charakteru partii. Niezależnie od faktu, że na początku analizowanego artykułu Đilas sugerował przecież, że zmiana modelu partii winna następować dopiero po rewolucyjnym przechwyceniu władzy. Takie podejście wiąże się z oceną Đilasa o słabościach partii komunistycznych, spowodowanych głównie „reakcyjną polityką sowieckiego rządu” przetwarzającego lub próbującego je przetworzyć „w agenturę swego hegemonizmu i monopolizmu"139. W ujęciu Đilasa występują wyraźne, choć niewypowiedziane otwarcie, sugestie o potrzebie obrony robotniczych interesów i walki o socjalizm zgodnie $\mathrm{z}$ regułami i zasadami charakteryzującymi politykę partii socjalistycznych i socjaldemokratycznych. Jest to oczywistym odejściem od poglądu

\footnotetext{
138 Ibidem, s. 135.

139 Ibidem, s. 136.
} 
wyrażanego przezeń w okresie powstawania Kominformu, że jedynie rewolucyjne zburzenie kapitalistycznych porządków może być właściwą drogą budowy nowego, sprawiedliwego ustroju społecznego ${ }^{140}$. Sugerowane partiom zachodnim w $1947 \mathrm{r}$. obecnie były porzucane właśnie z powodu wspomnianego przekonania o ich słabości i podporządkowaniu „wstecznej” polityce Kremla.

Po upływie dziesięcioleci Đilas napisze o czymś, o czym miał wiedzieć i ukrywać „samemu przed sobą”. A mianowicie, że w jego krytyce Związku Sowieckiego można było dostrzec wiele odniesień, które „przeważnie pośrednio, ale niewątpliwie dotyczyły także jugosłowiańskiego ustroju politycznego i gospodarczego”. Różni „towarzysze na górze" mieli dostrzegać te odniesienia w jego tekstach i tolerować je. Czasami dlatego, że wyrażali pewne skłonności do „demokratyzacji”, przede wszystkim zaś w rezultacie faktu, że „góra była sparaliżowana własnym, rozżarzonym antysowietyzmem" i siłą rzeczy pomijała niewygodne konsekwencje swej krytycznej postawy wobec polityki władców na Kremlu, dostrzegalne w tekstach Đilasa, okazując mu jedynie pewne "nadąsanie” i wysuwając „koleżeńskie zarzuty” ${ }^{41}$. W innym miejscu Đilas zasugeruje, że wspomniana tolerancja wynikała ze szczerego przekonania „większości na górze”, iż Jugosławia istotnie kroczy „nową, niebywale demokratyczną drogą", choć z drugiej strony „zapewne było w tym wiele iluzji i samooszukiwania”, które występują „,w każdej idealizacji własnego działania, szczególnie rewolucyjnego". Tak czy inaczej, w wyniku wewnętrznych i zewnętrznych uwarunkowań jugosłowiańska „biurokracja partyjna” została zmuszona do ustępstw ${ }^{142}$, do pewnego „przyczajenia”, a także zamazania swej ideologii. Należałoby jedynie ponownie podkreślić, że zgodnie z własnym zamysłem w ramach przedstawiania Stalina, ZSRS i systemu sowieckiego jako odstępstwa od marksizmu. Niemniej nadal była „zatwardziała i nieugięta w obronie własnej, uprzywilejowanej pozycji społecznej i materialnej ${ }^{143}$. Ta obrona ujawni się wyraźnie już wkrótce, po zgonie Józefa Stalina 6 III 1953 roku. W rezultacie zacznie powstawać nowa sytuacja polityczna, która stwarzała również nowe ramy dla twórczości i przemyśleń Đilasa oraz jego stosunków z innymi przywódcami ZKJ i Jugosławii.

Anti-Stalinist "heresy" in Yugoslav orthodoxy. Stalin, the USSR and Soviet system in Milovan Đilas political views in the years 1950-1952

In his article, Michał Jerzy Zacharias presents political thought of Milovan Đilas in the years 1950-1952 so in the period of a deep crisis in Yugoslav-Soviet relations. The crisis appeared as

${ }^{140}$ Co sugerowano głównie komunistom włoskim i francuskim, zob. M. J. Zacharias, Między marzeniami a rzeczywistościq̨..., s. 28-30 i przyp. 28, s. 29.

${ }^{141}$ M. Đilas, Razvoj mog političkog mišljenja, cz. 11, http://milovandjilas.rs/tekstovi/razvoj\%20 mog\%20političkog\%20misljenia.pdf.

${ }^{142}$ Zdaniem Aleksy Đilasa, syna Milovana wspomniane, tymczasowe ustępstwa były warunkowane antyjugosłowiańską polityką Stalina oraz potrzebą uzyskania wsparcia na Zachodzie, A. Đilas, Hronologija života..., s. 7.

${ }^{143}$ M. Đilas, Pad nove klase, s. 110. 
a result of Stalin's policy and Cominform's resolution of June 28th 1948. During those years Yugoslavia's leaders most severely and visibly criticised the Soviet system and tried to prove that they are "the true" orthodox Communists. As a result, a characteristic local "heresy" appeared - "heresy" in Yugoslav communist orthodoxy. The main representative of this "heresy" was Milovan Đilas, a prominent theoretician, ideologist and party propagandist. He abandoned his previous homage and panegyrics praising the Kremlin steward and made attempts to reveal that the USSR system is only "a state capitalism" where the dominating position was occupied by caste of political party bureaucracy. Such system is no different from the policy of western powers such as the United States. Similarly to those countries, Moscow cares about broadening its zone of influence and obtaining dominating position worldwide. In such conditions, "building" socialism or communism and supporting the forces which aimed at abolishing capitalist order outside the borders of the USSR became secondary, in fact ignored and not realised. As a result, "the true" Communists, mainly Yugoslav, must separate from Soviet bureaucrats and independently build foundations of a new system in the world.

In Yugoslavia, Đilas noticed the beginnings of the new system in self-governments, which formation was announced by the party and state leader Josip Broz Tito in June 1950. Nonetheless, Đilas was a very intelligent and perceptive politician and he noticed that Yugoslav self-governments are nothing but a façade that covers the same system as in the USSR with a dominant role of local party bureaucracy. With time, Đilas would identify the Yugoslav system with the Soviet one and eliminate it from political life of his country.

\section{Антисталинская „ересь” в югославской ортодоксии. Сталин, СССР и советская система в политических взглядах Милована Джиласа в 1950-1952 г2.}

В своей статьи Михал Ежи Захариас представляет политическую мысль Милована Джиласа в 1950-1952 гг, то есть в период глубокого кризиса в югославо-советских отношениях. Кризиса возникшего в результате политики Сталина и резолюции Коминформа от 28 июня 1948 г. Именно в эти годы лидеры Югославии наиболее отчетливо и резко подвергали критике советскую модель строя, одновременно пытаясь доказать, что именно они и есть „настоящие”, ортодоксальные коммунисты. В результате образовалась своеобразная, местная „ересь” в югославской коммунистической ортодоксии. Главным представителем этой „ереси” был Милован Джилас, влиятельный теоретик, идеолог и партийный пропагандист. Он бросил свои прежние почести и панегирики, воспевающие кремлевского властелина и все более и более отчетливо пытался доказать, что строй Советского Союза - это лишь „государственный капитализм”, в котором доминирующее положение занимает каста партийной политической бюрократии. Такой строй противоречит основным положениям марксизма и одновременно способствует империалистской политике Советского Союза. Она ничем не отличается от политики западных держав с США во главе. Так же как и эти государства - Москва заинтересована в расширении зоны своего влияния и достижении доминирующего положения в глобальном масштабе. В этих условиях „стройка” социализма или коммунизма в собственной стране, а также поддержка для тех сил, которые стремятся к свержению капиталистического порядка вне границ СССР становится делом второстепенным, по сути упущенным, неосуществимым. В результате, „настоящие” коммунисты, во главе с югославскими, должны отмежеваться от советских бюрократов и самостоятельно создавать фундаменты нового мирового строя.

Джилас замечал зачатки новой системы в Югославии в самоуправлении, которого образование, м. пр. под его влиянием, было объявлено руководителем партии и главой государства, Иосипом Броз Тито - в июне 1950 г. Тем не менее, Джилас был слишком интеллигентным и проницательным политиком, чтобы не заметить, что югославское 
самоуправление - это лишь фасад, за которым скрывается система идентична советской, с доминирующей ролью местной, отечественной партийной бюрократии. Со временем это приведет Джиласа к отождествлению югославской системы с советской и станет причиной его исключения из политической жизни собственной страны. 